\title{
WATER SCIENCE AND TECHNOLOGY BOARD ANNUAL REPORT 1989
}

\author{
Water Science and Technology Board \\ National Research Council
}

Washington, D.C. 1990

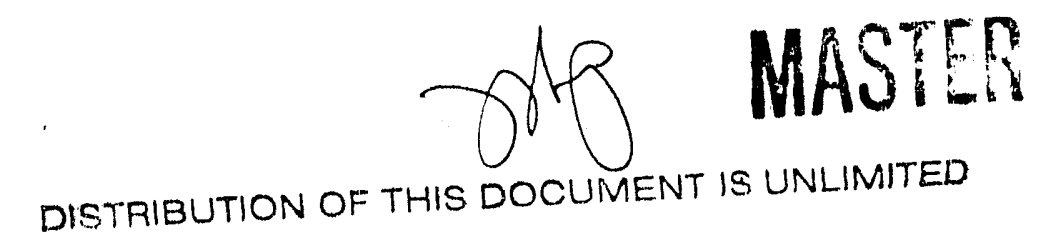


The Water Science and Technology Board is a unit of the National Research Council, which serves as an independent adviser to the federal government on scientific and technical questions of national importance. The National Rescarch Council, jointly administered by the National Academy of Sciences, National Academy of Engineering, and the Institute of Medicine, brings the resources of the entire scientific and technical community to bear on national problems through its volunteer advisory committecs. The Board's objective is to improve the scientific and technological basis for resolving important questions and issues associated with the efficient management and use of water resources.

\section{WATER SCIENCE AND TECHNOLOGY BOARD}

MAILING ADDRESS:

Water Science and Technology Board

National Research Council

2101 Constitution Avenue, N.W. (HA-278)

Washington, D.C. 20418

OFFICE LOCATION:

2001 Wisconsin Avenue, N.W.

Milton Harris Building, Suitc 278

TELEPHONE NUMBERS:

(202) 334-3422 (Commercial)

(202) 737-3422 (FTS - Incoming)

TELECOPIER:

(202) $334-2620$

ELECTRONIC MAIL:

BITNET - USERNAME@NAS 


\title{
THE WATER SCIENCE AND TECHNOLOGY BOARD
}

\section{Members}

Michael Kavanaugh, Chairman, James M. Montgomery Consulting Engineers, Walnut Creek, California

Norman H. Brooks, California 'astitute of Technology

Stephen Burges, University of Washington (through 6/30/89)

Richard A. Conway, Union Carbide Corporation, South Charleston, West Virginia

James Heaney, University of Florida, Gainesville

R. Keith Higginson, Idaho Department of Water Resources, Boise, Idaho (through 6/30/89)

Howard C. Kunreuther, University of Pennsylvania, Philadelphia

Luna B. Leopold, University of California at Berheley (through 6/30/89)

G. Richard Marzolf, Murray State University, Murray, Kentucky

Robert R. Meglen, University of Colorado at Denver

James W. Mercer, GcoTrans, Inc., Herndon, Virginia (through 6/30/89)

Donald J. O'Connor, HydroQual, Inc., Mahwah, New Jersey

Betty H. Olson, University of California at Irvine

P. Suresh C. Rao, University of Florida, Gainesville

Gordon Robeck, Consultant, Laguna Hills, California (through 6/37/89)

Patricia Rosenfield, The Carnegic Corporation of New York, New Y'ork

Donald D. Runnells, University of Colorado at Boulder

A. Dan Tarlock, Chicago Kent College of Law

Hugo F. Thomas, Department of Environmental Protection, Hartford, Cennecticut James R. Wallis, IBM T. J. Watson Research Center, Yorktown Heights, New York M. Gordon Wolman, The Johns Hopkins University, Baltimore

\section{Staff}

Stephen D. Parker, Director

Sheila D. David, Senior Staff Officer

Chris Elfring, Senior Staff Officer

Sarah Connick, Staff Officer

Wendy L. Melgin, Staff Officer (through 10/89)

Jeanne Aquilino, Administrative Assistant

Renee A. Hawkins, Administrative Secretary

Anita A. Hall, Senior Secretary

\section{DISCLAIMER}

\begin{abstract}
This report was prepared as an account of work sponsored by an agency of the United States Government. Neither the United States Government nor any agency thereof, nor any of their employees, makes any warranty, express or implied, or assumes any legal liability or responsibility for the accuracy, completeness, or usefulness of any information, apparatus, product, or process disclosed, or represents that its use would not infringe privately owned rights. Reference herein to any specific commercial product, process, or service by trade name, trademark, manufacturer, or otherwise does not necessarily constitute or imply its endorsement, recommendation, or favoring by the United States Government or any agency thereof. The views and opinions of authors expressed herein do not necessarily state or reflect those of the United States Government or any agency thereof.
\end{abstract}




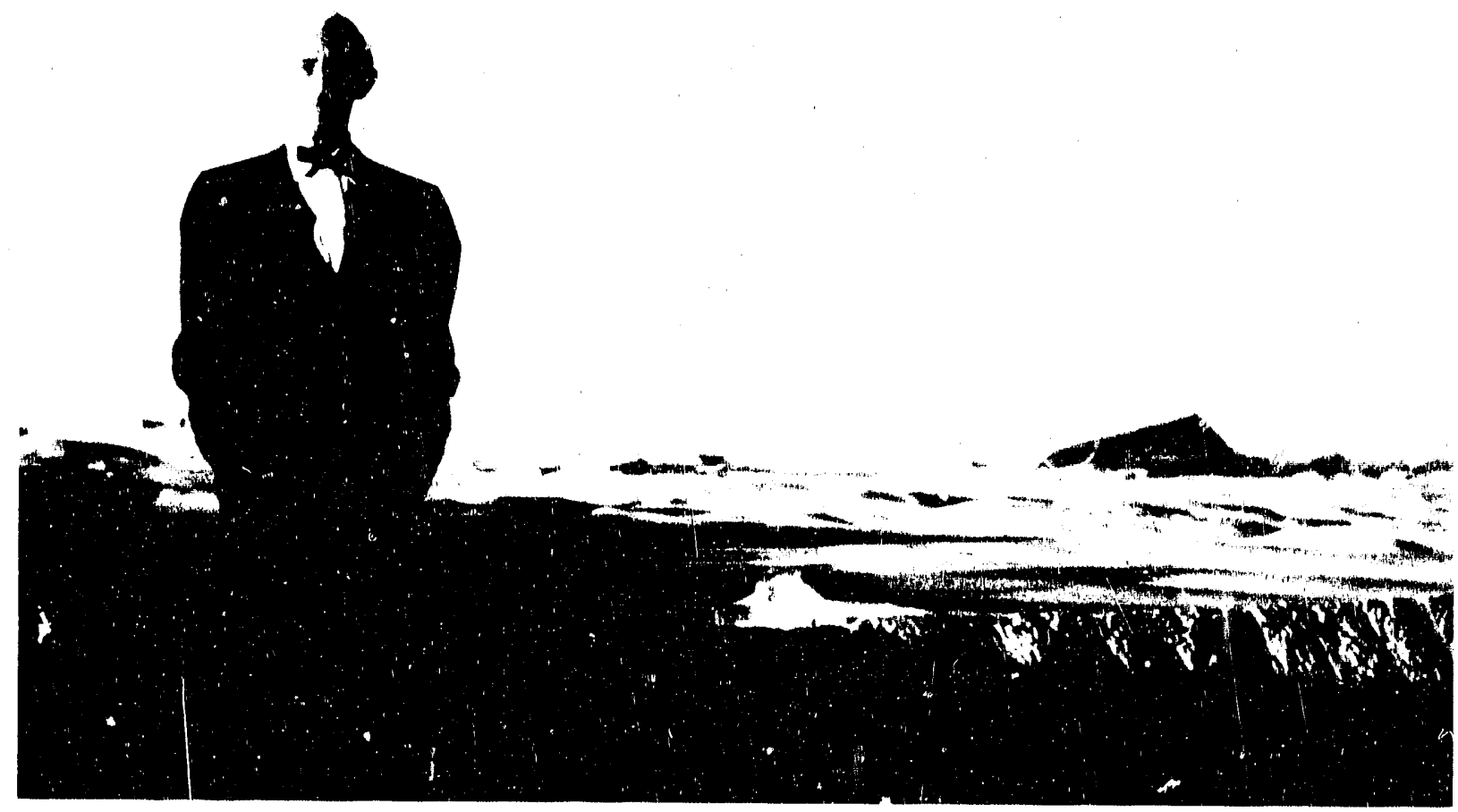

This issue is dedicated to

Dr. Abel Wolman 1892-1989.

Engineer, Scientist, Educator. and Advocate for Public Health

through Improved Water Supply and Sanitation. 
DR. ABEL WOLMAN was born in Baltimore, Maryland, June 10,1892, the fourth of six children of Polish immigrants. He received the Bachelor of Arts degrec from Johns Hopkins University in 1913 and hoped to become a physician. Instead, his family persuaded him to enroll in the newly opened Johns Hopkins School of Engineering where he received his Bachelor of Science in Enginecring with the first graduating class in 1915. His professional carecr had already started; he had been collecting water samples on the Potomac River for the U.S. Public Health Scrvice in 1912. After a year he joined the Maryland Department of Health, beginning an association which lasted until 1939.

While employed with the state Department of Health, he performed some of his most distinguished scientific research in water purification. During this period in the city of Baltimorc, the city's water supply sources were highly variable and of questionable quality. The Wolman family actually practiced water purification by tying a piece of cheesecloth around the water spigot in their home to filter out stones and dirt. Outbreaks of waterborne discase struck Baltimore and other American citics with alarming regularity.

Dr. Wolman and the late Linn Enslow, a chemist and former Johns Hopkins classmatc, made a leap forward in public health science when they developed a method 70 years ago of making drinking water safe by putting measured amounts of chlorinc in it, a procedure so common today that people cither take it for granted or are simply unaware of the practice.
Dr. Wolman's capacity and cnthusiasm for life and his work touched all who knew him. A member of the first delegation to the World Health Organ zation (WHO), he worked on water upply, wastewater and water resources throughout the world with WHO and the Pan American Organization. He advised international leaders on ways to bring a healthful water supply to their pcoples, and became probably the best known consultant on water and public health in the world. Wolman chaired the committec that planned the water system for the then new state of Isracl, and he helped Latin American nations to develop ways to finance their water systems. Dr. Wolman was professionally active until the time of his death on February 22, 1989.

Abel Wolman was truly a person who transecnded all political and social boundarics with his caring and knowledgc to make the world a healthicr and safer place in which to live. A member of both the $\mathrm{Na}$ tional Academy of Enginecring and the National Academy of Sciences, Dr. Wolman had a long association with the Water Science and Technology Board as a friend and advisor. In memory of Dr. Wolman, The Water Science and Technology Board has initiated the Abel Wolman Distinguished L.ceture Series. The first lecture, "Ethos, Equity, and the Water Resource," was delivered on Fcbruary 15, 1990 by Dr. Luna B. Leopold, Professor Emeritus, University of California, Berkelcy. 


\section{Contents}

MESSAGE FROM THE CHAIRMAN 1

1. OVERVIEW 3

2. ACTIVITIES COMPLETED IN 1989

3. CURRENT PROGRAMS 9

4. NEW ACTIVITIES BEGINNING IN $1990 \quad 18$

5. FUTURE PLANS: IN 1990 AND BEYOND 21

APPENDIX A

Reports Issued by the Water Science and Technology Board (1982-1989)

APPENDIX B

Meetings of the Water Science and Technology

Board and Its Subgroups During 1989

APPENDIX C

Terms of Reference 


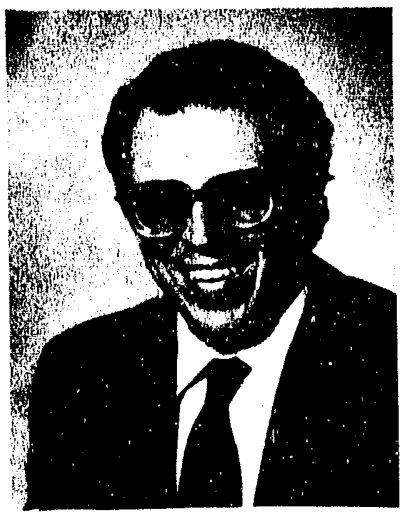

Michael C. Kavanaugh

\section{Message From The Chairman}

In the July 15, 1989 issue of THE ECONOMIST, the editorial writers hypothesized that over the next 40 years, world leaders will be as preoccupied with the environment as they were with defense issues in the previous 40 years. Thus, some of the world's political leaders have apparently accepted what many in the scientific community have long realized, that proper management of the environment is essential for survival on the planet. Certainly one of the major environmental issues facing the Unitcd States and the world is proper management of our water resources, a formidable task that reflects many of the conflicts inherent in the word "management."

It is in this context that the activitics and achievements of the Water Science and Technology Board over the past 7 years should be considered. Since it's inception in 1982, the Board has produced over 50 publications addressing a wide range of complex issues, with over 400 professionals contributing their time and energy in committec work. In the past year alone, the Board has completed, initiated, or continued 14 activities ranging from government program reviews to the publication through the National Academy Press of major reports with widespread interest.*

The diversity of activities undertaken by the Board, in response to requests of federal, state and local agencies, foundations, and other institutions concerned about water resoures management, is mirrored by the makeup of the Board itself. As you will read in the pages that follow, the Board draws on experts from the varied scientific, technical, legal, and institutional perspectives involved in resolving water resource management conflicts. Its overall mission, as dcfined in the charter of the National Rcsearch Council, is to advise the federal government on scientific and technical issucs related to water resource management in its broadest sense. The Board of fers a unique forum that can provide a balanced, objective, and critical review of the actions of the federal government and other institutions as they affect the nation's water resources.

This annual report provides a glimpse into the workings of the Board, including both current and past activities. What you will find makes interesting reading. The Board has shown a willingness to take on some tough problems, and to provide unique and global perspectives on resolving some of these problems. A number of recurring issues can be scen and it is instructive to extract some of these to best illustrate what the Board does.

One theme is the compatibility of science and public policy, illustrated in both the Board's fifth colloquium concerning rcmediation of contaminated soil and ground water and in a new and challenging undertaking to evaluate urban coastal wastewater management issues. Committees on Western Water Management Chañe and IrrigationInduced Water Quality Problems address the

\footnotetext{
*Examples: Irrigation-Induced Water Quality Problems, Managing Coastal Erosion, and Ground Water Models: Scientific and Regulatory Applications.
} 
thorny issue of equity in water resources allocations. The Board provides a unique retrospective cvaluation of regulatory strategies and risk management decisions through several committecs, including the Committee on Coastal Erosion Zone Management and on hazardous waste and flood management. A number of the Board's committees have addressed the dilemma of managing water resources in the face of poorly defined uncertainty, including an earlicr committec on drought management and the current committec advising the Burcau of Reclamation on the impact of possible climate variability is $n$ their operations. The Board of ten addresses the diffuse interfaces among science, and technology, and the legal, institutional, and cconomic constraints so critical in resolving water resource issues, as demonstrated in the recent report of the Committec on Ground Water Modeling Assessment. Finally, research and educational necds for improving water resource management are the focus of several undertakings, including the Committec on USGS Water Resources Research and the Committec on Opportunities in the Hydrologic Sciences.

An annual report can be a uscful summary of an extensive activity, but it may not convey the tremendous dedication of the Board members, committee voluntecrs, the federal agency representatives and others with whom we interact, and the outstanding staff of the WSTB. It is personally very gratifying to work with such a distinguished and hard working group of pcoplc, who contribute so much of their time to make the activitics of the Board a success, and assure that the reports produced by the Board arc of the highest quality and have the maximum impact on all parties involved in water resource management. Thank you all for your contributions. 


\section{Overview}

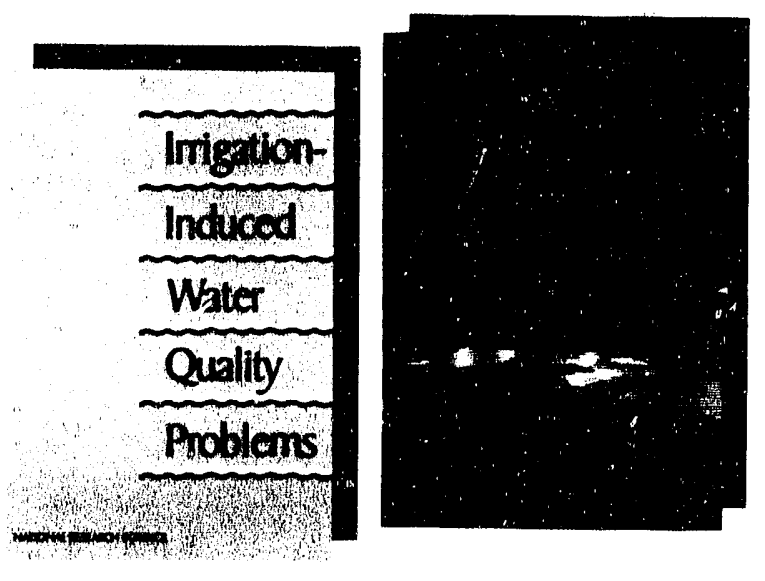

This report summarizes the activitics of the Water Science and Technology Board (WSTB) and its subgroups during 1989, its seventh year of existence. It describes current and recently completed projects, new activities scheduled to begin in 1990, and plans for the future. The report also includes information on Board and committec memberships, program operational features, and reports produced during the past several years.

This annual report is an introduction to the WSTB and its program for the year. Many of our readers are people about to become involved in WSTB activitics, either as appointed volunteers, recipients of advice, or sponsors of WSTB efforts. Others are individuals who know only pieces of the program but are generally interested in other aspects.

The WSTB is intended to be a dynamic forum, a mechanism by which the broad community of water science, technology, and policy professionals can help assurc high quality national water programs. As such, the Board considers outreach and conimunications of much importance. We welcome inquiries and suggestions concerning our activitics and will provide more detailed information on any aspect of Board projects.

The WSTB is a unit of the National Research Council, the operating element of the National Academy of Sciences and the National Academy of Enginecring, which exist by virtue of an 1863 act of Congress requiring the National Academy of Sciences to provide scientific and technological assistance to the lederal government upon request. While the WSTB works closcly with executive agencies of the federal government in a scientific advisory capacity, it is not a part of the government. The intellectual resources and expertise available to the Board extend across many disciplines and types of organizations concerned with water and related natural resources. These resourecs and the Board's independence afford a unique forum for addressing various issues of importance to the nation.

The WSTB was organized in 1982

the focal point for water-related activitics within the National Research Council (NRC). It was created out of recognition of the increasing importance of water resourccs to our nation and the expectation that a standing unit within the NRC could be a prominent and valuable resource. The Board's scope covers the traditional scientific and engineering aspects of water resources and the economic, legal, institutional, educational, and social aspects as well.

The WSTB generally meets three times 
cach year, and its nincteenth meeting was held in September 1989. Twenty-one volunteers from universities and industry served as WSTB members during 1989, with collective interest and expertise that covered a wide range of subjects. Several hundred others served on study committees, as report reviewers, as government agency representatives to the program, and in other important capacities. At WSTB ricetings, ongoing projects are monitored, new initiatives are developed, and research needs and other issues are considered.

In addition to these "business" aspects, meetings of the WSTB foster communication within the water resources community. Most agencies with water-related responsibilitics have liaison representatives who reg!llarly attend and actively contribute at W'STB mectings. Additional communication occurs among the lia ison members, who occasionally mect as a group to address WSTB-rclated and other matters, and through a quarterly WSTB NEWSLETTER, produced by the WSTB staff. In addition, in 1989 WSTB members and staff met informally on several occasions with agency representatives and others to discuss various aspects of the program and plan activitics. In 1989, the Board hosted its firth colloquium on emerging issues in water science and technology and launched a new distinguished lecture scrics in honor of Dr. Abel Wolman, who passed away in February 1989.

Studies indertaken by the WSTB can be initiated in either of two ways. Most commonly, topics are chosen for study after a request by a government agency or other body. At times, the WSTB will develop plans for a study it considers especially important, sccking financial support from appropriatc organizations. Board members play an important leadership rolc in all WSTB studies, and they are responsible for activitics such as project development, committce nominations, and report reviews. WSTB studics, however initiated, address research, science, engincering, and technology related to the development and management of water and related resources, especially in relation to national objectives and priorities.
The Board's principal products are its reports (see Appendix A). They range from "letter" reports, generally focused on particular agency programs and read by a lim. ited, but important, audience of government managers, to major publications distributed by the thousands by the National Academy Press that address more general areas of science, technology, and policy. In all cases, the reports have had and are having important effects, and the WSTB's visibility and credibility have increased with each successive project.

Most WSTB reports are written by special committecs and panels of experts. These committees are supported by a small staff which is critical to the effective and timely performance of all committce activitics. The staff helps ensure that the group's tasks are carcfully formulat ! and clearly understood, that all NRC policies and procedures are followed, that the professional community has been surveyed in the selection of committec members, and that expert technical assistance and logistical support is available through the critical Academy pecr revicw, process and publication, and dissemination processes.

In 1989, financial support for the WSTB's general program and specific project activitics was provided by many sponsors, including: the U.S. Environmental Protection Agency, U.S. Geological Survey, Burcau of Reclamation, Fedcral Emergency Managcment Agency, U.S. Department of Encrgy, National Science Foundation, U.S. Nuclear Regulatory Commission, the State of California, Elcctric Power Rescarch Institute, Mobil Corporation, the Soil Conservation Scrvicc, National Acronautics and Space Administration, the Metropolitan Water District of Southern California, Ford Foundation, East Bay Municipal Utility District, the Office of Surfacc Mining, Living Lakes Inc., Chevron USA, Inc., the Agency for International Development, and the National Rescarch Council itself. The total WSTB budget for 1989 totaled about $\$ 1.2$ million, four times greater than in 1983 (its first full year of opcration). 


\section{Activities Completed in 1989}

\section{MANAGING COASTAL EROSION}

Much of the population of the U.S. now lives within a two-hour drive of a coast and millions of inlanders travel much farther to spend vacations or transact business in coastal locations. Since the advent of the Interstate Highway System in the 1960's, increasing demand for coastal resources has expanded and changed settlement patterns along accessible tidal and Great Lakes shorelines. These population and economic pressures have transformed the lightly developed shorelines of earlier years into high density resorts and urban complexes. An increasing number of these strucures are built on erosion-prone shorelines where the continual danger of their collapse presents the potential for substantial property loss.

In response to growing concern about this problem, the U.S. Cungress gave the Federal Emergency Management Agency (FEMA) responsibility for incorporating coastal erosion into its National Flood Insurance Program (NFIP). In 1988 an NRC committec was appointed (with oversight by the Marine Board and the WSTB) to provinc advice to FEMA on appropriate crosion management strategies, and supporting data and analytic methods, to be administered through the NFIP.

A report completed in November 1989 (available from the National Academy Press in 1990) explores major questions surrounding a national policy on coastal erosion: Should the federal government be in the business of protecting developers and individuals who build in erosion-prone areas?
Is government involvement an intrusion on private enterprise? How should such a program be implemented? Can such a program prompt more responsible management of coastal areas? The report provides valuable information about the natural processes of coastal erosion and erosion's interaction with human activities--such as the critical balance between environmental concerns and the substantial pressure for continued shoreline development.

The report also reviews aspects of the National Flood Insurance Program and the Upton-Jones Amendment. This Amendment adopts an approach that encourages retreat from eroding shorelines. Included in the committee's reviews are lessons to be learned from state shoreline management programs and experiences, with detailed vicws of programs in four coastal states; the potential for predicting future shoreline changes, with details on sources of data and predictive models; and the research and development that will be necessary to develop a national erosion policy.

\section{Committee}

William L. Wood, Chairman, Purdue University

Robert G. Dean, University of Florida

Martin Jannereth, Michigan Department of Natural Resources

Judith T. Kildow, Massachusetts Institute of Technology

Stephen P. Leatherman, University of Maryland

Bernard LeMchaute, University of Miami 


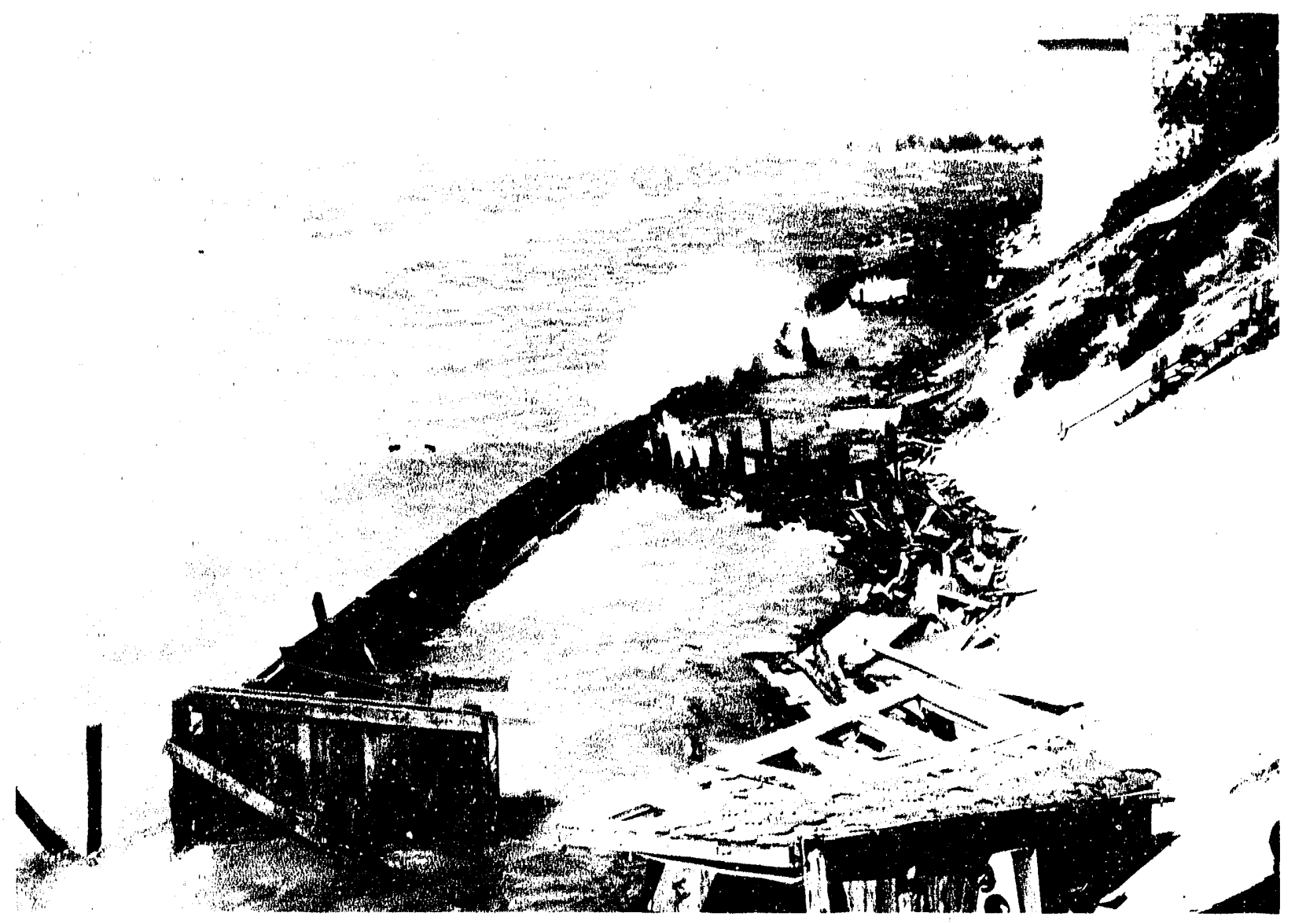

An increasing number of structures built along the nation's vast coastlines are on crosion-pronc shores, where they face the danger of collapse or damage. In response to mounting property losses, Congress gave the Federal Emergency Management Ageney responsibility for incorporating coastal crosion into its National Flood Insurance Program. Ihe WSTB was asked to help in this task, and the report Managing Coastal Erosion is an example of the Board's ability to provide rocused program assessments for federal agencics. (Photo from Michigan Department of Natural Resources.) 
David W. Owens, University of North Carolina

Rutherford H. Platt, University of Massachusetts

Robert L. Wiegel, University of California

\section{IRRIGATION-INDUCED WATER QUALITY PROBLEMS}

Irrigation brings many tencfits to socicty, but it also can bring probicms. The irrigation-induced selenium ontamination at Kesterson National Wildlife Refuge and the ongoing problems with irrigation drainage throughout California's San Joaquin Valley illustrate the conflicts that can arise between the interests of agriculture and the crivironment. The phenomenon, according to the WSTB's recentiy relcased report "IrrigationIndueed Water Quality Problems," is one that should not be dismissed as an aberration because selenium at these sites is just one cxample of a trace element being concentratcd to problematic levels as a result of irrigation. The underlying issuc is clcar: irrigation, like many other uses of water, degrades water quality. The contaminants and the impacts may vary, but similar episodes are already being discovered at other sites throughout the West.

The comrnittec's inal report looks at this type of problem broadly-its causes and consequences as well as how cconomic, legal, and other factors impede our ability to respond--and suggests ways to study the complex issues involved. Together with some 15 letter reports issued over the 5 years of the committee's existence, this report attempts to warn federal and state policymakers about the difficultics inherent in resolving irrigation-related water quality problems. It represents a synthesis of the committec's advice to the San Joaquin Valley Drainage Program and the National Irrigation Water Quality Program. This effort was sponsored by the Department of the Interior and the State of California.

\section{Committee:}

Jan van Schilfgaarde, Chairman, Agricultural Research Service
Ernest E. Angino, University of Kansas

Magriet F. Caswell, University of California, Santa Barbara

Edwin H. rlark II, Delaware Department of Natural Resources and Environinental Control

Charles T. DuMars, University of New Mexico

Wilford R. Gardner, Liversity of California, Burkeley

Rolf Hartung, University of Michigan

Charles D.D. Howard, Charles Howard and Associates, Consultant

L. Douglas James, Utah State University

William M. Lewis, Jr., University of Colorado at I.enver

Ishwar P. Murarka, Eleciric Power Research Institute

Albert L. Page, University of California, Riverside

Merlyn B. Recves, League of Women Voters

Danicl E. Willard, Indiana University

$G$. Richard Marzoilf (ex officio, IISTB nember), Murray State University

Gordun $G$. Robeck, (ex officio. WSTB mem. her), Lagu.a Hills, California

\section{GROUND WATER AND SOIL CONTAMINATION REMEDIATION: TOWARD COMPATIBIE SCIENCE, POLICY, AND PUBLIC PERCEPTION}

Sirce 1985, the WSTB has conducted an annual colloquium to provide a forum for discussion of a current issue, identilied by the Board, that might not otherwise receive adequate attention.

The Board's fifth colloquium, held in Washington, D.C., April 20-21, 1989, rocused on how science influences policy and public perceptions where cleanup of ground water and soil contamination is concerned. The public, press, and Congress are often unfamiliar with the scientific constraints involved in soil and ground water cleanup policy, given the complex scientific questions underlying these issues. With this in mind, the authors of the papers presented and other participants were invited not only for their technical knowledge concerning cleanup levels of contaminated soil and ground water, but also for their experience with 
public perception of such contamination issues and the statutes and laws that regulate how state and gcvernment agencies respond.

A steering committee of Board members and others, working closely with the WSTB staff, organized the colloquium program. Twelve papers were presented by recognized experts affiliated with federal and state regulatory agencies, environmental and public interest groups, private industry, consulting firms, universities, the U.S. Air Force, and law firms. The prenenters included scientists and regulators involved in setting cleanup levels, as! well as the affected parties.

The final report, issued in 1990, has two major sections: an overview and the papers prepared by individuals authors. Colloquium Chairman, Richard A. Conway and the steering committee prepared the overview based on the background papers, the presentations, and discussion generated at the colloquium.

\section{Steering Committee:}

Richard A. Conuay, Chairman. Union Carbide Corporation
Stephen Cordle, U.S. Environmental Protection Agency

James W. Mercer, Geotrans, Inc.

David W. Miller, Geraghty \& Miller, Inc.

P. Suresh C. Rao, University of Florida

\section{Principal Contributors:}

Glen D. Anderson, Environmental La ir Institute

Larry Canter, University of Oklahoma

Christopher J. Corbett, U.S. Environmental Protection Agency

Douglas C. Downey, Tyndall Air Force Base

Robert H. Harris, Environ, Inc.

David R. Lincoln, CH2M-Hill Consulting

Douglas M. Mackay, University of California at Los Angeies

Perry L. McCarty, Stanford University

Glenn Paulson, Illinois Institute of Technolog $y$

Rena I. Steinzor, Spiegel \& McDiarmid

William A. Wallace, CH2M-Hill Consulting

William J. Walsh, Pepper, Hamilton, \& Scheetz

Stephen R. Wassersug, U.S. Environmental Protectiun Agency

Marcia E. Williams, Browning-Ferris Industrics, Inc. 


\section{CURRENT PROGKAM}

\section{OPTIONS FOR WESTERN WATER MANAGEMENT CHANGE: THIRD PARTY EFFECTS}

As the West grows and its population becomes more urban, it faces increasing conflicts over how best to allocate and manago wate: supplies. Water transfers are a much-discussed water management approach. Yet important questions about the effects of water transfers remain unanswered. Of particular concern in this study are the effects on third partics--those intercsts beyond the direct sellers and buyers. One of ten overlooked third party, for instance, is the environment (c.g., the impact of water transfers on water quality or on habitat availability).

Environmental val ws are increasingly important to society but it is uncertain whether the institutional setting--the combination of laws, policy, and tradition--has kept pace with this change in socictal values. Water transfers are becoming more common, but mechanisms to put into practice our broadened understanding of the inherent costs and bencfits, and incorporate a heightened sensitivity to the third party efiects, of ten are lacking.

This WSTB study is using a case study approach to improve our understanding of the nature, purpose, and consequences of water transfer?, with special emphasis on possible impediments and third party ef fects. The Truckec-Carson basin in Nevada, tinc Arizona cxperience, conflicts in Colorado's Front Range region, and other examples exploring the role of transfers in western water management will be exam. ined in an attempt to draw out some broader insights to guide the federal role in such transfers. A variety of sponsors support this work, including the Ford Foundation, the Bureau of Reclamation, the Environmental Protection Agency, the Metropolitan Water District of Southern California, and East Bay Municipal Utility District.

\section{Committee:}

\section{A. Dan Tarlock, Chairman, Chicago Kent} Coliege of Law

D. Craig Bell, Western States Water Council Bonnic Colby, University of Arizona

Leo M. Eisel, Wright Water Enginecrs

David H. Getches, University of ColoradoBoulder

Thomas Graff, Environmental Defense Fund

Frank Gregg, University of Arizona

R. Keith Higginson, Idaho Department of Water Resources

Marvin E. Jensen, Colorado State University

Duncan T. Patten, Arizona State University

Clair B. Stalnaker, U.S. Fish and Wildlife Service

Luis S. Torres, Southwest Research Information Center

Richard Trudell, Amcrican Indian Lawyer Training Program

Henry J. Vaux, Jr., University of California-Riverside

Susan Williams, Gover, Stetson. Williams, and West

Jan van Schilfgaarde, Agriculture Rescarch Service 


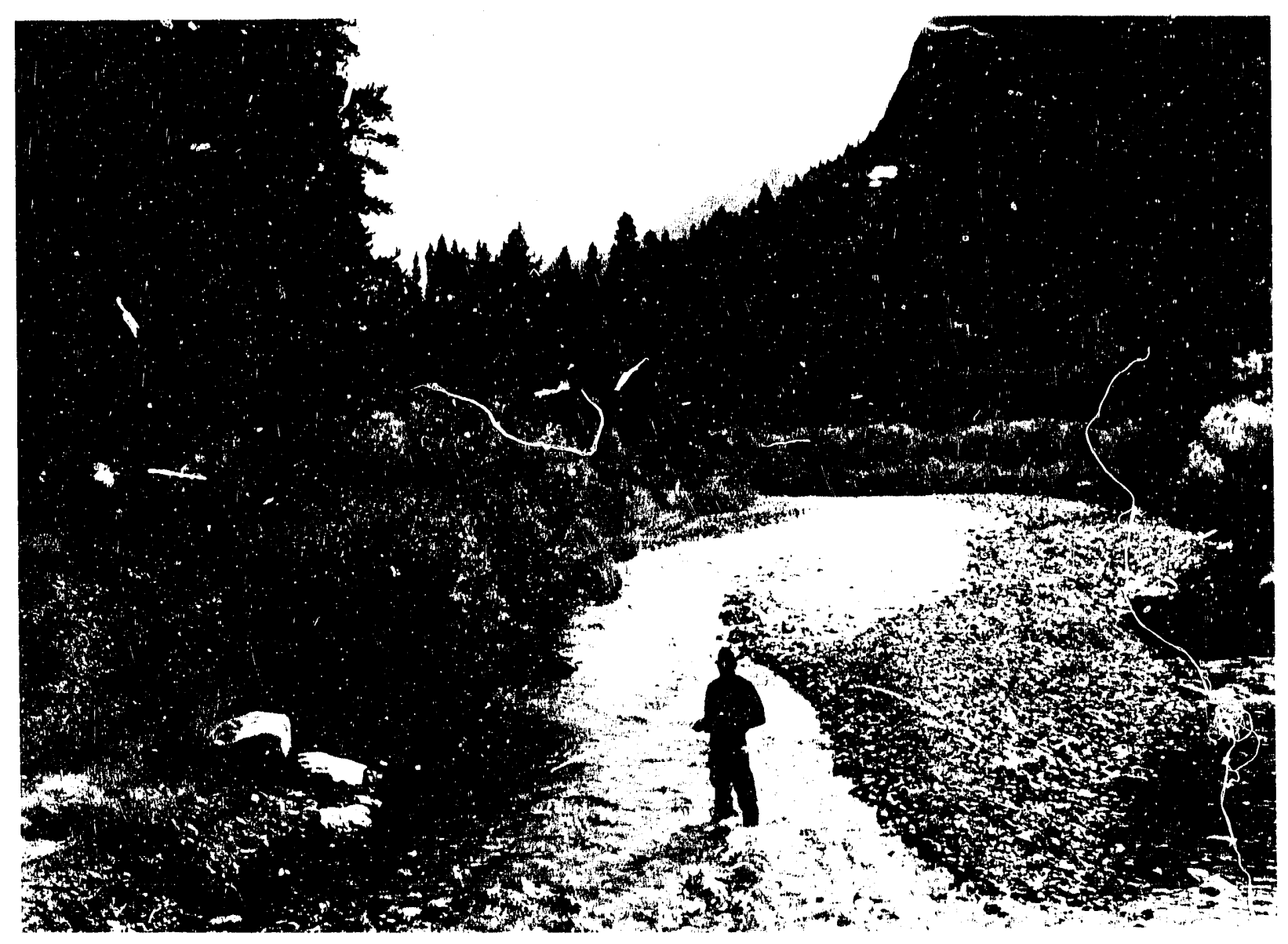

In the 20 ycars since the first Earth Day was celcbrated, the nation's values have undergone an evolution, and many citizens now place more emphasis on environmental protection. The WSTB's activities reflect this trend--some current stucies with an environmental management focus deal wit: the impacts of water transfers in the West, the restoration of aquatic systems, and the National Water Quality Assessment Program. (Phoro from D. Schuhart, Soil Conservation Scrvice.) 


\section{ASSESSMENT OF OPPORTUNITIES IN THE HYDROLOGIC SCIENCES}

In late 1987 the WSTB began an important study of opportunities in the hydrologic sciences. The study includes a review of the current status of the subfields of hydrology and of their coupling with related geosciences and biosciences, the identification of promising new frontiers and opportunities for the hydrologic sciences to help improve water and environmental management, and the development of a framework for hydrologic education and research. This study results from an increased awareness by the hyrologic community of the need for fundamental advances in hydrologic science to generate solutions to emerging complex problems of water technology, and from the realization that the time has come for hydrology to become better established as a science alongside other recognized geosciences.

The study is assessing our understanding of the natural rescrvoirs and fluxes involved in the global hydrologic cycle. The focus is on continental water and the physical, chemical, and biological processes interacting with the continental water, such as crosion, sedimentation, vegetation growth, and chemical weathering. Oceans, lakes, the atmosphere, glaciers, and icesheets are considered to the extent that they interact with the hydrologic cycle. The spatial scales of concern vary from the micro-processes of soil moisture to the global scale of hydroclimatcological change. The time scales of concern also vary broadly.

The committce's product will be a report, currently undergoing external peer review and expected to be published by the National Academy Press in the summer of 1990. The report will provide guidance for the development of the hydrologic sciences and attempt to secure acceptance for hydrology within the scierece establishment on a par with other geosciences. Although the book is being written for a broad audience, from the informed lay public to research scientists and university educators, the principal audience will be science policymakers and research managers in government agencies and other organizations having geoscience programs.

Support for this project was provided by the National Science Foundation, National Aeronautics and Space Administration, U.S. Geological Survey, National Research Council, U.S. Forest Service, National Weather Service, Army Research Office, and the Mobil Corporation.

\section{Committee:}

Peter S. Eagleson, Chairman, Massachusetts Institute of Technology

Wilf ried H. Brutsaert, Cornell University

Samuel C. Colbeck, U.S. Army Cold Regions Research and Engineering Laboratory

Kenneth W. Cummins, University of Pittsburgh

Jeff Dozier, University of California, Santa Barbara

Thomas Dunne, University of Washington

John M. Edmond, Massachusetts Institute of Technology

Vijay K. Gupta, University of Colorado

Gordon C. Jacoby, Lamont-Doherty Geological Observatory

Syukuro Manabe, National Occanic and Atmospheric Administration

Sharon E. Nicholson, Florida State University

Donald R. Nielsen, University of California, Davis

Ignacio Rodriguez-Iturbe, University of Iowa

Jacob Rubin, U.S. Geological Survey

J. Leslie Smith, University of British Columbia

Garrison Sposito, University of California, Berkeley

Wayne T. Swank, Cowecta Hydrologic Laboratory

Edward J. Zipser, Texas A\&M University

Stephen J. Burges, ex of ficio, WSTB member. University of Washington

\section{USGS WATER RESOURCES RESEARCH}

Since 1985, the Committec on USGS Water Resources Rescarch has provided advice to and worked with U.S. Gcological Survey (USGS) seientists and managers on a variety of matters. Originally established to provide guidance relating to the institutes and grants provisions of the Water Resources Research Act of 1984 (Public Law 98-242), the committec's activitics have expanded to cover both intramural and cx- 
tramural research programs of the USGS and many of the agency's other programs.

In addition to the institutes and grants programs, the committec's attention has focused on various aspects of the $\mathrm{Na}$ tional Water Quality Assessment Program, the agency's National Research Program in water resources, climate change ind water resources, and other topics.

In 1989, the full committce met twice in addition to mectings of smaller work groups. The committee began planning a report that will highlight a varicty of issues relevant to future USGS roles and programs. The report will be ruture looking, addressing the "right mix" of program clements in USGS district ofrices in coming decades, the role of research in the agency, the agency's data networks, and relation with other entitics, including, universitics.

\section{Committee:}

Walter R. Lynn, Chairman. Cornell University

James W. Biggar, University of California, Davis

Edward J. Bouwer, The Johns Hopkins University, (throuk, 12/89)

Lenore S. Clesceri, Rensselacr Polytechnic Institute

Thomas Dunne, University of Washington, (through 12/89)

Robert A. Goldstein, Electric Power Research Institute

Marjoric M. Holland, Ecological Socicty of America

George M. Hornberger, University of Virginia

Philip C. Kearney, USDA, Agriculture Research Service

Shlomo P. Neuman, University of Arizona

Kenneth W. Potter, University of Wisconsin

Elgene ivi. $\bar{K}$ asmusson, University of Mary" land

Clifford S. Russcll, Vanderbilt University

Philip Singer, Stanford University

Hugo F. Thomas, Connecticut Department of Environmental Protection, 'through 12/89)

Kenneth N. Weaver, Maryland Ceological Survey

\section{GROUND WATER RECHAKGE IN SURFACE-MINED AREAS}

The availability of coal as a source of energy is important to our modern style of living and economy. The production of coal is a complex, heavy industry that can have many impacts on the environment, especially on the hydrologic functions of the areas in which mining occurs, such as water quality and rainfall-runoff-ground water recharge relationships. Presently, approximately 60 percent of the coal production in the United States is by surface mining.

To consider and minimize the potential regative impacts of surface mining, Congress passed the Surface Mining Control and Reclamation Act (SMCRA) of 1977, which contains requiremenrs relative to the hydrologic character of mined arcas. Among these is a requirement that, in the restoration of the landscape, mining opcrators restorc the "recharge capacity" of mined areas to approximate pre-mining conditions. To get guidance for interpreting and implementing this requirement, in 1988 the Office of Surface Mining Rcclamation and Enforcement (OSM) of the U.S. Department of the Interior asked the WSTB for assistance.

In responsc, in March 1989 the WSTB formed a committec to assess of technologies for ground water recharge cvaluation. The scope of work includeci:

(1) definition of the term "recharge capacity;"

(2) identification of methods for estimating ground water recharge in mining areas;

(3) a critique of the strengths and weaknesses of existing approaches with respect to tiicir hydrologic validity;

(4) recommendations for preserving ground water recharge in comparable terms for pre-mining "natural" and post-mining "restored" conditions;

(5) identification of considerations that are relevant to analysis of hydrologic functions of mined locales;

(6) identification of any research required to strengthen the recommended 
approach; and

change, if warranted.

recommendations of policy

The assignment was difficult owing

to a number of factors, not the least of which is the paucity of accurate historical data on hydrologic functions in the of ten remote areas where surface mining occurs. Further, there was the aspect that the impact of mining might be less than the magnitude of uncertainty associated with the ability to quantify recharge. Nonetheless, recommendations are provided in the committee's report that should allow relevant parties to comply with the spirit of the Act, i.e., to assure minimum negative disturbances to the hydrologic system in surface mined areas.

This committee's report, available in March 1990, includes chapters on regulatory aspects of the issue, the hydrology of ground water recharge, pre-mining conditions in coal mining regions, methods and impacts of mining, and techniques for quantifying ground water recharge rates. Although not the major charge of our report, a discussion of the relevant water quality issues is included.

\section{Committee:}

Herman Bouwer, Chairman. Water Conservation Laboratory, USDA

Robert E. Beck, Southern Illinois University

Corale L. Brierley, Salt Lake City, Utah

C. Thomas Haan, Oklahoma State University

George M. Hornberger, University of Virginia

Robert J. Luxmoore, Oak Ridge National Laboratory

John C. Sencindiver, West Virginia University

James R. Wallis, IBM Watson Research Center

William W. Woessner, University of Montana

INTERNATIONAL SOIL AND

WATER RESEARCH AND

DEVELOPMENT

Early in 1990, after nearly a year of pre-project planning, a new Committee on
International Soil and Water Research and Development was appointed jointly by the WSTB and the Board on Science and Technology for International Development (BOSTID) of the NRC's Office of International Affairs. This new committee was established at the request of the U.S. Agen" cy for International Development (AID). AID is active world-wide in developing countries in the general area of soil and water science and technology. Some of the issues with which AID soil and water programs are concerned include: erosion, deforestation, salinity, water supplies, public health, water quality, impacts of potential climate change, and others. The agency is in the process of reorganizing and bringing more focus to its programs oriented to problems in these areas through establishment of a new Soil and Water Agricultural Collaborative Research and Development Network (SWAN).

The new committee will provide both technical and policy advice to the SWAN "network" through senior AID staff. The committee will operate somewhat in the continuing advisory style of the WSTB's existing Committec on USGS Water Rcsources Rescarch. It would also conduct more in-depth deliberative studies of $1 \mathrm{ech}$ nical topics.

The committee's initial activity of the committee is likely to be an assessment of the scientific, technological, and management needs of the network. This will involve a general review of natural resources problems in developing countries, identification of the most pressing problems, and an evaluation of AID's capability to respond to these problems in countries where financial assistance is being considered.

The committee will mect several times e: hyear, including one major mecting including most "network" representatives. This project has the potential to bring the expertise of a broad community of scientists and enginecrs to bear on some of the world's major environmental problems.

\section{Committee:}

Leonard Berry, Chairman, Florida Atlantic University 
Susanna B. Hecht, University of California, Los Angeles

Charles C. Howe, University of Colorado

Jack Keller, 'tah State University

Charles B. McCants, Raleigh, North Carolina

Hugh Popenoe, University of Florida

Paul P. S. Teng, University of Hawaii

Goro Uehara, University of Hawaii

P. Suresh C. Rado, ex of ficio, WSTB member. University of Florida

\section{GLEN CANYON ENVIRONMENTAL STUDIES}

Management of water resources has been and will remain a critical issue for the western United States. The Bureau of Reclamation originally was created to reclaim the arid west and provide cconomic stability in the newly annexed portion of the nation. Subscquently, additional goals were added to the Burcau's mission, such as providing municipal water supplics and supplying energy through the operation of hydroclectric generating facilitics.

New trends and changing circumstances have required a recvaluation of the Burcau's mission and its prioritics. Morc attention is being given to alternative means of supplying water through improved system management and reevaluating allocation prioritics. Water conservation and environmental protection have become major public concerns.

In 1986, the Burcau of Reclamation, recognizing these changing circumstances, requested assistance in cvaluating and interpretating the Glen Canyon Environmental Studics (GCES) bcing conducted concerning the impacts on the environment of the lower Colorado River and operation of the Glen Canyon Dam. The WSTB saw this request as a special opportunity to cxamine a set of investigations designed to cvaluate the effects of storage and power dam operation on basic carth science phenomena. Furthermore, the WSTB saw an opportunity to examine the integration of science and technology with cconomic, political, and legal institutions, and to bring thinking from diverse disciplines to bear on procedures liued to investigate large rivers.

The committee produced its first report, River and Dam Management, in December 1987. Although the committec concluded that the Bureau of Reclamation could not make any. long-term decisions concerning the managemert of Glen Canyon Dam based on the GCES, it concluded that the studies have produced some excellent information, and many research results represent new knowledge that will contribute to the information base about the Colorado River. The committec has continued to provide scientific adviec to the rescarchers and to revicw future study plans for Phase II. Two letter reports werc issued in 1988.

As the committce continucs advising the GCES team until January 1991, it has undertaken a new responsibility to organize a symposium to review existing infermation about the Colorado River downstream from Glen Canyon. Approximately ten background papers will be presented by scholars known for their experience with water science issues in the southwestern United States and with the Grand Canyon/Glen Canyon in particular. A published procecdings from the NRC will be produced in 1990.

Another charge to the committec is to review the draft final plan for future rescarch below Glen Canyon Dam. A formal letter report should be issued on this review in 1990.

\section{Committee:}

G. Richard Marzolf, Chairman, Murray State University, Murray, Kentucky

David Dawdy, Consulting Hydrologist, San Francisco, California

William Graf, Arizona State University

W. Michacl Hanemann, University of California, Bcrkeley

Trevor C. Hughes, Utah State University

William M. Lewis, University of Colorado, Boulder

A. Dan Tarlock, Chicago Kent College of Law

Duncan T. Patten, ex officio, Arizona State University 


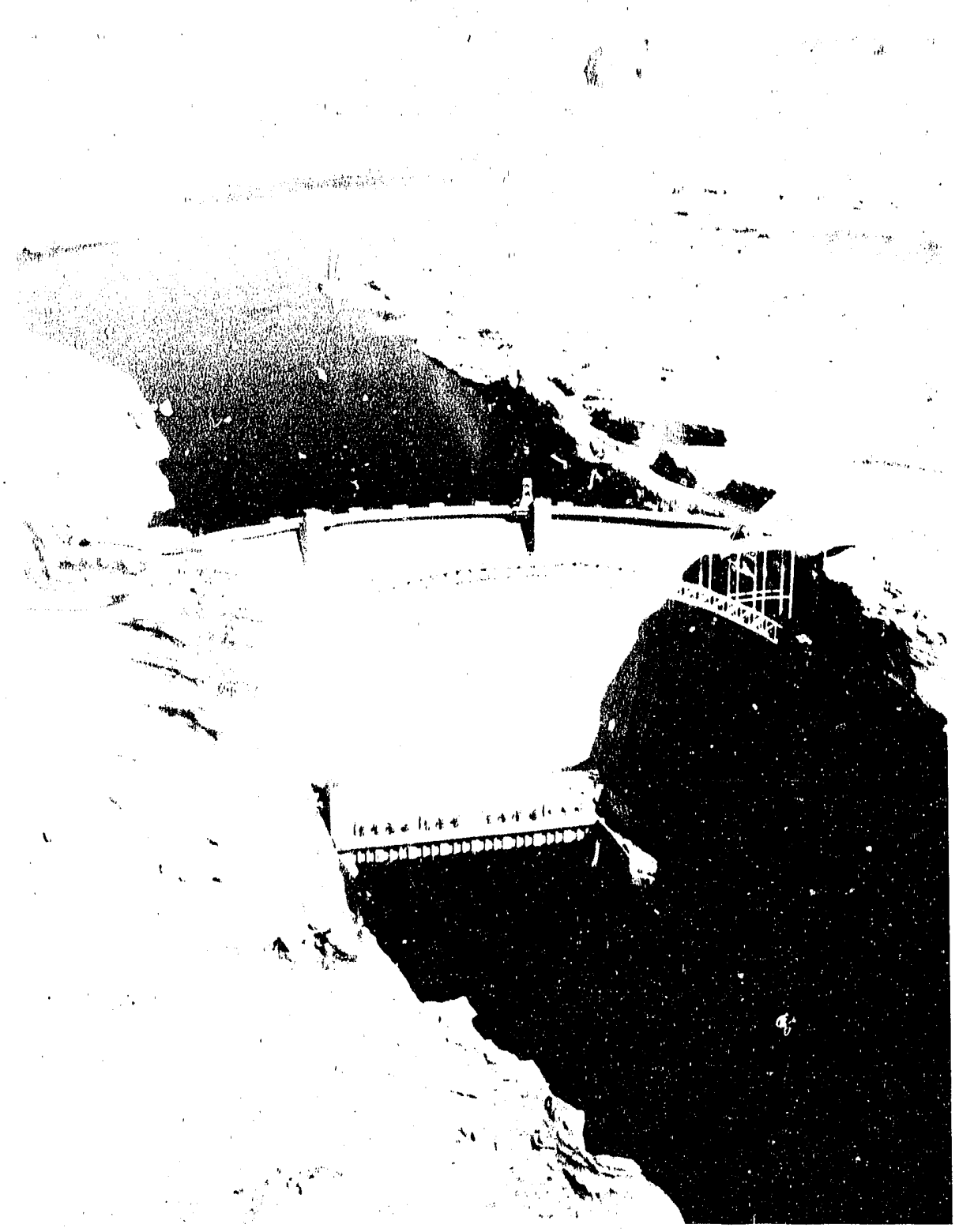

Onc recurring theme among WSTB projects is the management of water resources. As prioritics have shifted over time, there have been inercased calls for more careful balancing in federal water management policies. The WSTB's revicw of the Burcau of Reclamation's Glen Canyon Environmental Studies deals with this need for balance between the needs for hydropower and the maintenance of the natural ecology of rivers. (Photo from the U.S. Department of the Interior). 


\section{RESTORATION OF AQUA'TIC SYSTEMS: SCIENCE, TECHNOLOGY, AND PUBLIC POLICY}

In 1934 Aldo Leopold said that "The time has come for science to busy itself with the earth itself. The first step is to reconstruct a sample of what we had to begin with." The concept expressed here-restoration--has been defined in an ongoing WSTB study as "the return of an ecosystem to the closest approximation to its previous condition prior to the disturbance of concern." This study is particularly relevant as suciety is increasingly conceried with correcting some of the environmental mistakes of the past.

The committec is reviewing many restoration activities involving lakes, wetlands, and rivers. They also are looking at several large aquatic systems to show how these water bodies interact. The scope of work includes: (1) formulating critcria by which to choose the restoration projects to be reviewed; (2) evaluating selected restorations with respect to their scientific basis, performance over time, the technologies were fulfilled, and why it was a success or failure, taking into consideration the political and regulatory aspects; (3) identifying common factors of successful restoration projects, and based on this review, providing a recommended list of criteria for successful restoration efforts io serve as a model for future efforts at restoring aquatic systems; and (4) identifying federal policy, policy conflicts, and responsible agencies that contribute substantially to the continuing degradation of lakes, rivers, and wetlands in the United States.

After a two-year evaluation, the committee will issue a final report. The study is sponsored by seven organizations, both federal and private, including Chevron USA, Inc., U.S. Army Corps of Engincers, Living Lakes, Inc., the U.S. Environmental Protection Agency, the Burcau of Reclamation, the Soil Conservation Service, and the National Rescarch Council.

\section{Committee:}

John Cairns, Chairman, Virginia Polytechnic Institute
G. Ronnie Best, University of Florida John J: Berger, Consultant, El Cerrito, California

Patrick L. Brezonik, University of Minnesota

Stephen R. Carpenter, University of Wisconsin

G. Dennis Cooke, Kent State University

Donald L. Hey, Wetlands Research Inc.

Jon A. Kusler, Association of State Wetland Managers

Claire L. Schelske, University of Florida

Leonard Shabman, Virginia Polytechnic Institute

Rebecca R. Scharitz, University of Georgia

Richard E. Sparks, Illinois Natural History Survey

Soroosh Sorooshian, University of Arizona

James T.B. Tripp, Environmental Defense Fund

Daniel E. Willard, Indiana University

Joy B. Zedler, San Diego State University

Betty $\mathrm{H}$. Olson, ex officio, WSTB member. University of California at Irvine

M. Gordon Wolman, ex officio, WSTB member. The Johns Hopkins University

\section{EVALUATION OF THE USGS \\ NATIONAL WATER QUALITY ASSESSMENT PILOT PROGRAM}

Human health and environmental health are inextricably linked to our nation's water quality. As our population grows and our water resources become more developed and stressed, water quality becomes a more important component of our political, economic, social, and environmental decisionmaking. Such decisionmaking should not proceed without adequate information and understanding.

In 1986, the USGS proposed and initiated the pilot National Water Quality Assessment program to evaluate national trends in both surface and ground water quality. Subsequently, the Board was asked to undertake a two-year evaluation of the pilot program and to make recommendations concerning implementation of a fullscalc program, including its technical design and potential usefulness for establishing and evaluating national policics. A committee was established which has been engaged in studies since mid 1988. 
In September 1989, the committec issued an interim report to the USGS. The committee stated that it was convinecd that a national-scalc, long-term water quality assessment is in the best interest of the nation and that the USGS is well qualified to implement the proposed NAWQA program.

A final reporting concerning fullscale implementation of the program and a critique of its design should be issued in summer 1990.

\section{Committee:}

Richard S. Engelbrecht, Chairman, University of Illinois

K. C. Bishop, Chevron USA, Inc.
Sandra L. Blackstone, University of Denver College of Law

Michael E. Campana, University of New Mexico

Margaret Concuitt, The Procter \& Gamble Company

Robert C. Cooper, University of California, Riverside

David L. Freyberg, Stanford University

James Geraghty, Geraghty \& Miller, Inc. Judy L. Meycr, University of Georgia

Donald J. O'Connor, Manhatten College Susan Stafford, Oregon State University James Heancy, ex officio, WSTB member. University of llorida

Kenneth Poticr, ex officio, University of Wisconsin 


\section{New Activities Beginning in 1990}

\section{CLMATE UNCERTAINTY AND WATER RE: UURCES MANAGEMENT}

The possibility of global climate variability, whether natural or human-induced, is a topic of great concern among both scicntists and the public at large. Although there is growing acknowledgement that mechanisms are in place that might bring about significant warming of Earth's surface, there is little agrecment as to the specific impacts that might result and thus what actions we might need to take to adapt to changed conditions.

In late 1989, a new committec was appointed to help the Bureau of Reclamation improve its capability to manage its extensive system of water projects in the 17 western states in light of the possible hydrologic uncertainty posed by prospects of global climate change. It is an effort to assist them ir the initial development of alternative operating strategies--to be anticipatory rather than reactive. And whether significant human-induced climate changes occur or not, such preparation should provide guidance useful in coping with the more normal perturbations that occur within climatic cycles.

The committee will first convene a substantive colloquium on climate uncertainty and water management. There, the committee and other scientists, engineers, and Bureau of Reclamation staff will share current information and debate the ranges of management responses that might be possible. The committee will prepare a report designed to help the agency as it develops a work plan for a comprehensive resuarch program to investigate further the issues and problems related to climate change and water management. Other activities relevant to the matice of improving water management may follow. This effort is supported by the Bureau of Reclamation.

Committee:

Stephen J. Burges, Chairman, University of Washington

Robert E. Dickinson, National Center for Atmospheric Research

Kenneth D. Frederick, Resources for the Future

Roger E. Kasperson, Clark University

Bruce A Kimball, USDA/Agricultural Research Service

Daniel P. Sheer, Water Resources Management, Inc.

\section{OPPORTUNITIES TO IMPROVE WASTEWATER MANAGEMENT FOR URBAN COASTAL AREAS}

As is happening in many areas of environmental management, decisionmakers responsible for wastewater management in coastal areas are facing difficult judgements when trying to balance environmental effectiveness and economic efficiency. As part of this debate, the WSTB has recently begun a new study of considerable public interest with the appointment of its Committee on Wastewater Management lor Urban Coastal Areas.

Whether because they have failed to modernize their sewage systems, identificd new pollution problems, or outgrown the capacity of their current systems, coastal 
urban centers around the country--and in fact the world--face the same general need to set priorities for wastewater manal ement and choose technologies that are must effective and appropriate for long-term conditions. The experience gained in science and engineering during the past two decides since passage of the Clean Water Act in 1972 provides the nation the opportunity to open new horizons in the decision making process.

The study will aid in the development of needed waste management strategies for the future that maximize innovative, flexible, and cost-cffective options for coastal. environments. The study is timely not only because of experience gained in recent years, but duc to a high level of public commit. ment to improving the occan and coastal environment, the availability of better tools to assess and manage risk, and the fact that governments at all levels are faced with difficult allocations of scarce financial resources.

The study will examine issues such as the balance of costs and environmental benefits, and the degrec of flexibility needed to account for regional conditions, and new information regarding system performance.

Sponsors include the U.S. Environmental Protection Agency, National Science Foundation, National Academy of Engincering, the City of San Dicgo, and the Frecman Fund of the Boston Section of the American Society of Civil Engincers.

\section{Committee:}

John J. Boland, Chairman, The Johns Hopkins University

Blake P. Anderson, County Sanitation Districts of Orange County

Norman H. Brooks, California Institute of Technology

William M. Eichbaum, The Conservation Foundation

Lynn R. Goldman, California Department of Health Services

Donald R. F. Harleman, Massachusetts Institute of Technology

Robert W. Howarth, Cornell University

Robert J. Huggett, College of William and Mary

Thomas M. Keinath, Clemson University

Alan J. Mearns, National Occanic and Atmospheric Administration
Charles R. O'Melia, The Johns Hopkins University

Larry A. Roesner, Camp, Dresser, \& McKee, Inc.

Joan B. Rose, University of South Florida

Jerry R. Schubel, Staite University of New. York, Stony Brook

Richard A. Conway, ex officio, WSTB member, Union Carbide Corporation

\section{PLANNING FOR AND REMEDIATING IRRIGATION-INDUCED WATER QUALITY PROBLEMS}

\begin{abstract}
Although salinity problems have long been known to be associated with irrigated agriculture, the problems caused by trace element accumulations have only recently been recognized. The bird deaths and deformities at Kesterson National Wildlife Refuge in 1982 provided the first clearly identified example of this type of problem, and sparked a broad west-wide research of fort to identify similar problem sites. This multiagency effort, the National Irrigation Water Quality Program, has to date reviewed more than 600 sites and identified more than 22 sites in 13 states as having high potential for such problems. Further site identification and evaluation efforts are underway, and planning activitics for how to deal with the problems identified are beginning.

Until recently, the NIWQP received some guidance from the WSTB'S Committec on Irrigation-Induced Water Quality Problems. At this committee's termination, the Department of the Interior requested the WSTB to form a new committce to give guidance specifically to the NIWQP. The new committee will, in part: host a joint meeting with NIWQP's ficld stafr and management where the preliminary results of the ongoing site identification rescarch will bc shared; critique NIWQP plans and approaches; write a concise final report assessing the strengths and weaknesses of the NIWQP strategy. The Department of the Interior will sponsor this activity.
\end{abstract}

\section{Committee:}

(To be appointed) 


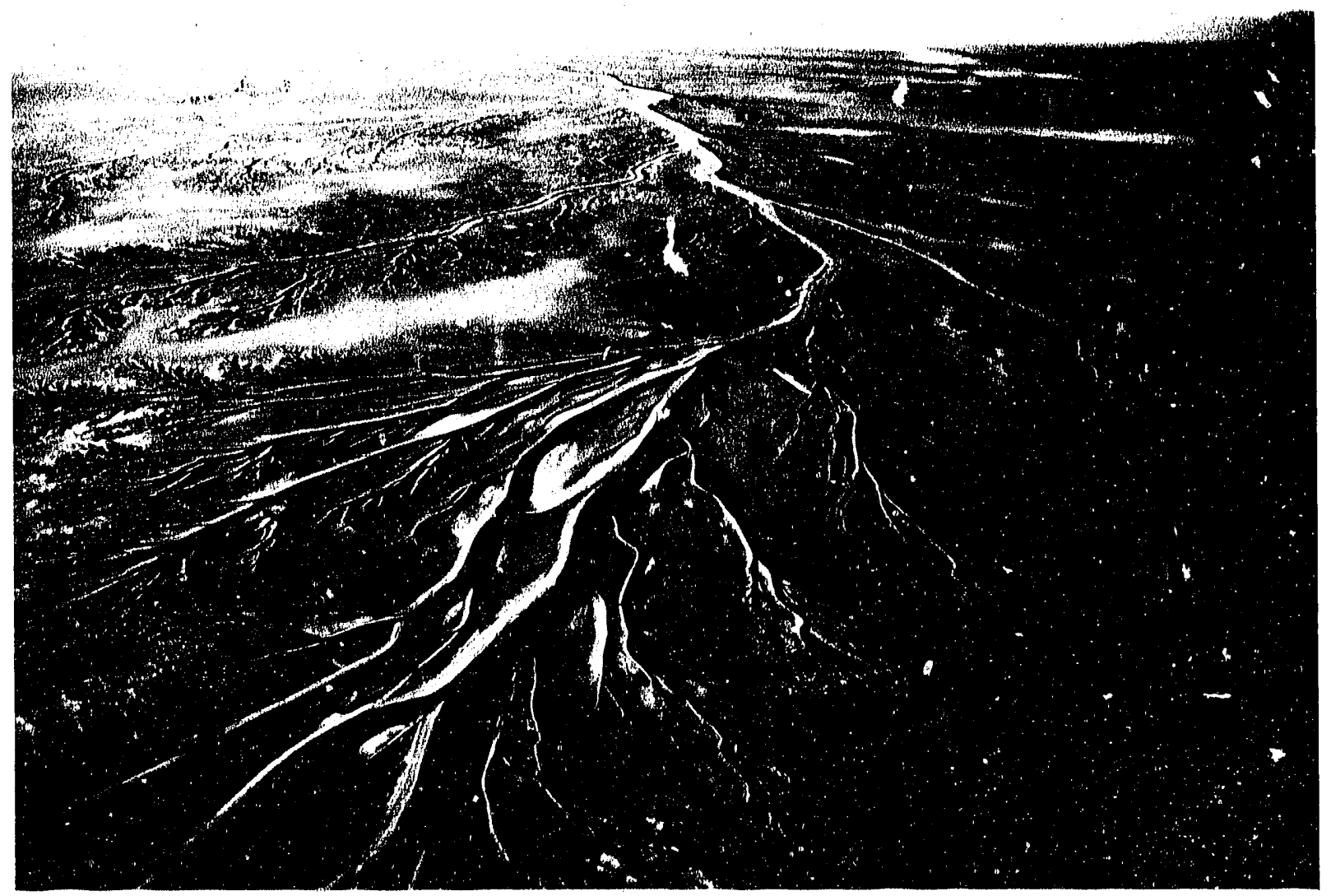

Looking to the future, the WSTB hopes to continuc to provide an objective perspective on the nation's most important water resource issucs. The Board will maintain a blend of both broad and focused studies, and will continue to deal with both the technical and institutional issues that arisc. (Photo shows a channel network formed by the cbbing tide in the Gulf of California.) (Photo from Anne Griffiths Belt for the National Geographic Socicty.) 


\section{Future Plans: 1990 and Beyond}

\section{EMERGING TECHNOLOGIES IN WATER TREATMENT}

With the arrival of 1990 and the 20th anniversary of Earth Day, the nation and the world are committed more than ever before to protecting environmental values. In some areas, however, it appears that technology is unable to mect increasingly stringent standards. Water treatment is one such area--including the treatment of municipal, industrial, and agriculture wastewater; the remediation of water resources at hazardous waste sites; and the treatment of water sources.

Some experts argue that progress is being slowed by barriers that discourage technologically innovative companies and the people who invest in them. Yet the nature of these barricrs is not well understooc because they represent a mix of technical and institutional factors that are not casily separated. Should this study be pursued, it would craluate the status of water treatment technologies, assess the adequacy of technological development in this sector, and consider whether this sector will be able to achisve the environmental requirement that are likely to be set in the future. It would pay special attention to the nation's international competitiveness in this field. The WSTB might elect to pursuc this topic via a series of focused symposia or other formats. Both federal and private sources of funding are being investigated.

\section{ENVIRONMENTAL MONITORING AND ASSESSMENT PROGRAM}

In September 1987, at the initiative of then Administrator Lee Thomas, the Environmental Protection Agency's Office of Research and Development (ORD) directed its scientists to develop an integrated strategy to improve the agency's ability to assess the risks to natural ecological systems at the regional scale from current and cmerging environmental pollutants.

The first proposed step in the development of the integrated ecological research strategy is creation of the Environmental Monitoring and Assessment Program (EMAP). This program has been proposed to begin in FY 1990 to compliment EPA's Acid Deposition, Global Climate Effects, and Stratospheric Modification Research Programs. The goal of EMAP is to identify, collect, organize, and analyze environmental monitoring data and report periodically to the Administrator on the current status and trends in indicators of the condition of the nation's ecosystems.

In late 1989, the WSTB received a request from ORD to provide a scientific review of EMAP's surface water quality assessment program. EMAP's surface water component shares certain broad goals with the USGS's proposed National Water Quality Assessment Program (NAWQA) currently under review by the WSTB.

Since the EMAP program will cover much more than water quality, the NRC's Board on Environmental Studies (BEST) has also been requested to play a rolc, by providing a review of the terrestrial (forests, deserts and range, and agroecosystems) and wetlands portion of EMAP. Thus, the study project will be developed jointly by the WSTB and BEST to insure appropriate integration among the reviews.

It is envisioned that a joint BEST/ 
WSTB oversight committee will be established to oversee two committees reviewing different components of the EMAP. The study committees will most likely be appointed and begin their review in the fall of 1990.

\section{REGIONAL ASSESSMENT OF POTENTIAL FOR GROUND WATER CONTAMINATION: EVALUATION OF CURRENT TECHNIQUES AND FUTURE OPPORTUNITIES}

In February 1990, the WSTB hosted a planning conference to help develop plans for a new study of techniques for assessing ground water vulnerability which may be underway before the end of 1990. The idea for this study arose out of the WSTB's tradition of looking ahead in the broad field of water resources, anticipating topics of future importance.

Ground water quality protection has become a major national environmental concern as discoveries of contamination duc to hazardous waste disposal or pesticide use have resulted in the closure of drinking water wells and highlighted the importance of this vital resource. A number of techniques have been developed to assess the potential for contamination of ground water on an arcal basis in order to make decisions regarding land use.

Use of simulation models and various empirical numerical rating techniques have been proposed for evaluating ground water vulnerability at both local and regional scales. For example, EPA uses the numerical ranking scheme DRASTIC to assese contamination potential on the basis of the physiographic and hydrogeologic. Similar Delphi rating schemes are being developed and used by several state environmental agencies to regulate pesticide use. The relative merits of models versus rating schemes have been debated in the literature and by $E^{\text {P } A}$ in deciding registration of Aldicarb prsticide use. The Aldicarb case is seen as a emplate for all future decisions made by the agency on pesticide registration.

The use of Geographic Information Systems (GIS) is becoming popular for inventorying, archiving, retricving, and displaying spatial data needed in these approaches for cvaluating vulnerability. GIS coupling to numerical rating schemes and to simulation models allows the production of computergenerated thematic maps displaying contamination potentials or vulnerability of land areas (at county-level or higher spatial scales). However, the varying levels of data quality and scales of the spatial data bases supporting GIS introduce great uncertainty in the reliability of these vulnerability maps. Questions as to how to validate the predictions (i.c., the GIS thematic maps) through sampling or monitoring also need to bc resolved.

This WSTB initiative would examinc the scientific basis for and the relative merits or limitations of various schemes for evaluating vulnerability of soils, surface waters, and ground waters. Recommendations could be made on the appropriateness of the schemes within the regulatory framework. Technical issues on data quality and uncertainty of vulnerability assessments could also be addressed.

Support for this initiative will bc sought from EPA, USGS, and the Department of Agriculture. This study is likely to be underway by the fall of 1990 . 


\section{Appendix A \\ Reports Issued by the Water Science and Technology Board (1982-1989)*}

\section{MANAGING COASTAL EROSION}

$1990,160 \mathrm{pp}$.

This report provides information about the natural processes of coastal crosion and the effect of human activity on those processes. The cornmittee chairman was William L. Wood, Purdue University. The report is available from the National Academy Press, 2101 Constitution Avenue, N.W., Washington, D.C. 20418. List price: $\$ 24.50$.

\section{GROUND WATER MODELS: SCIENTIFIC AND REGULATORY APPLICATIONS}

$1990,300 \mathrm{pp}$.

This report addresses scientific aspects and the use of ground water flow and contaminant transport modeling in the regulatory process. The committec was chaired by Frank W. Schiwartz, Ohio State University. The report is available for $\$ 29.95$ from the National Academy Press, 2101 Constitution Avenue, N.W., Washington, D.C. 20418.

\section{IRRIGATION-INDUCED WATER QUALITY PROBLEMS}

1989, $104 \mathrm{pp}$.

This report addresses how irrigation can endanger water quality, and how eco- nomic, legal, and other factors impede our ability to respond to water quality problems. It explores how to study these froblems, unraveling complex issues and cliri. fying the varying perspectives of farmers, environmentalists, scientists, and other key figures. The chairman of this committce was Jan van Schilfgarde, Agricultural Research Service. The report is available from the National Academy Press, 2101 Constitution Avenue, N.W., Washington, D.C. 20418. Cost: $\$ 24.95$.

\section{INTERIM REPORT OF THE COMMITTEE: ON NATIONAL WATER QUALITY ASSESSMENT PILOT PROGRAM (September 25, 1989)}

$1989,8 \mathrm{pp}$.

The first report from the committec provides USGS with an interim summary of its evaluation of the NAWQA program. It concludes that a national, long-term water quality assessment is necessary and that the USGS is well qualified to imple-ment the proposed program. A final review of the NAWQA program will be issued by Junc 1990. The committee chairman is Richard S. Engelbrecht, University of Illinois.

\section{GREAT LAKES WATER LEVELS: SHORELINE DILEMMAS}

1989, $149 \mathrm{pp}$.

This is the fourth report from the

\footnotetext{
*Two reports completed in 1989, published in 1990.
} 
WSTB series of colloquia on emerging issues in water science and technology. It addresses hydrometeorological, engineering, and land management and policy issues related to fluctuations in Great Lakes water levels. John J. Boland of The Johns Hopkins University, chaired the colloquium. The report is available in limited quantity at no cost from the Water Science and Technology Board, 2101 Constitution Avenue, N.W., Washington, D.C. 20418.

\section{LETTER REPORT OF THE COMMITTEE ON IRRIGATION-INDUCED WATER QUALITY PROBLEMS} (June 9, 1989)

This letter report addresses the U.S. Department of the Interior's NIWQP and contains comments in response to a briefing of proliminary data from the NIQWP's second set of reconnaissance studies. It provides suggestions to improve data uniformity and identification of the causes of identified problems, and it calls for the NIWQP to synthesize the myriad data into a comprehensive analysis with systematic conclusions.

\section{LETTER REPORT OF THE COMMITTEE ON IRRIGATION-INDUCED WATER QUALITY PROBLEMS \\ (September 11, 1989)}

This letter report from the Subcommittec on Economics, Policy, and Systems Analysis to the SJVDP discusses the continued development of the WADE computer model and the need to be frank about both its strengths and weaknesses. The necessity of outside peer review is stressed. The letter also comments on the SJVDP's progress in conducting legal and sociological analyses.

\section{LETTER REPORT OF THE COMMITTEE ON IRRIGATION-INDUCED WATER QUALITY PROBLEMS} (October 5, 1989)

This letter report expresses strong dissatisfaction with the political influences that have directed the SJVDP to look for solutions only within the confines of the San Joaquin Valley. This committce secs this as a short-sighted approach and again urges policymakers to address the longterm impacts of irrigated agriculture.

\section{LETTER REPORT OF THE COMMITTEE ON IRRIGATION-INDUCED WATER QUALITY PROBLEMS (December 30, 1988)}

1988, 3 pp.

The third letter report from the Subcommittec on Quality Assurance/Quality Control stresses the continued importance of quality assurance and quality control activities to the San Joaquin Valley Drainage Program (SJVDP). The subcommit"ee was chaired by Robert R. Meglen, University of Colorado at Denver. The report is available at no cost from the Water Science and Technology Board, 2101 Constitution Avenue, N.W., Washington, D.C. 20418.

\section{LETTER REPORT OF THE COMMITTEE ON GLEN CANYON ENVIRONMENTAL STUDIES} (July 11, 1988)

1988, 8 pp.

The first letter report from the committec recommends the Burcau of Reclamation establish a science rescarch advisory group to be placed at the Department of the Interior level. G. Richard Marzolf of Murry State University in Kentucky chairs this committec. The letter report can be obtained at no cost from the Water Science and Technology, 2101 Constitution Avenue, N.W., Washington, D.C. 20418. 


\section{LETTER REPORT OF THE COMMITTEE ON GLEN CANYON ENVIRONMENTAL STUDIES (December 19, 1988)}

1988, 2 p.

This is the second letter report from the committee emphasizes the recommendation that the Department of the Interior establish a senior science advisory group and that the chief scientist or principal investigator be retained through an Interagency Personnel Agreement to provide long-term continuity for the investigation. The committee is chaired by G. Richard Marzolf, Murray State University, Kentucky. The report is available at no cost from the Water Science and Technology Board, 2101 Constitution Avenue, N.W., Washington, D.C. 20418.

\section{LETTER REPORT OF THE COMMITTEE ON USGS WATER RESOURCES RESEARCH (August 1, 1988)}

1988, 3 pp.

The third letter report from the committee concerns funding for and reauthorization of the Water Resources Research Act of 1984, P.L. 98-242 which enables the extramural institutes and grants programs administered by the U.S. Geological Survey. The committec chair was Betty H. Olson of the University of California Irvine. The report is available from the Water Science and Technology Board, 2101 Constitution Avenue, N.W., Washington, D.C. 20418 .

\section{HAZARDOUS WASTE SITE MANAGEMENT: WATER QUALITY ISSUES}

$1988,224 \mathrm{pp}$

This report, a collection of papers from a colloquiur. sponsored by the WSTB, discusses ground and surface water cleanup levels at hazardous waste sites. Michacl Kavanaugh, James M. Montgomery Consulting Engineers, chaired the colloquium and authored an overview. The report is available for $\$ 24.50$ from the National Academy Press, 2101 Constitution Avenue, N.W., Washington, D.C. 20418.

\section{ESTIMATING PROBABILITIES OF EXTREME FLOODS: METHODS AND RECOMMENDED RESEARCH}

1988, 144 pp.

This report provides scientific examination of a variety of techniques available for characterizing very rare floods. It includes both a general overview and looks in detail at statistical and runof model. techniques. The committee was chaired by Jared L. Cohon of The Johns Hopkins University. The report is available for $\$ 15.95$ from the National Academy Press, 2101 Constitution Avenue, N.W., Washington, D.C. 20418 .

\section{RIVER AND DAM MANAGEMENT: A REVIEW OF THE BUREAU OF RECLAMATION'S GLEN CANYON ENVIRONMENTAL STUDIES}

1988, $203 \mathrm{pp}$.

This report provides recommendations to the Department of the Interior concerning the performance and results of the Glen Canyon Environmental Studics (GCES). It reviews the Bureau of Reclamation's planning and management of this project; the integration of the GCES results into a decisionmaking report; and the utility of the GCES results for management of the Colorado River, the Grand Canyon, and the operations of the Glen Canyon Dam. The committee is chaired by G. Richard Marzolf, Kansas State University. The report is available in limited quantitics from the Water Science and Technology Board, 2101 Constitution Avenue, N.W., Washington, D.C. 20418. 


\section{LETTER REPORT OF THE COMMITTEE ON IRRIGATION-INDUCED WATER QUALITY PROBLEMS}

(July 28, 1987)

1987, 3 pp.

In its fouth letter report, the Committee on Irrigation-Induced Water Quality Problems describes some signs of progress, including the program's effort to better define goals and objectives; initial steps taken io consider economic, legal, and institutional factors; and the establishment of a Citizens Advisory Committee. The committee chairman was Jan van Schilfgaarde, USDA-ARS, Fort Col!ins, Colorado. The report is available from the Water Science and Technology Board, 2101 Constitution Avenue, N.W., Washington, D.C. 20418.

\section{LETTER REPORT OF THE COMMITTEE ON IRRIGATIOIN-INDUCED WATER QUALITY PROBLEMS}

(July 28, 1987)

1987, $7 \mathrm{pp}$.

In its first letter report, the Subcommittee on Economics and Policy of the CIIWQP reports it was encouraged that the San Joaquin Valley Drainage Program (SJVDP) had begun to consider economic, social, legal, and institutional issues in their evaluation of alternative solutions. The subcommittee chairman was Margrict Caswell, University of California-Santa Barbara. The report is available from the Water Science and Technology, 2101 Constitution Avenue, N.W., Washington, D.C. 20418.

\section{LETTER REPORT OF THE COMMITTEE ON USGS WATER RESOURCES RESEARCH (July 13, 1987)}

1987, 2 pp.

The second letter report from the committec contains a current assessment of the Section 105 extramural research grants program. The committee chairman was Betty H. Olson of the University of California, Irvine. The report is available from the Water Science and Technology Board, 2101 Constitution Avenue, N.W., Washington, D.C. 20418.

\section{LETTER REPORT OF THE COMMITTEE ON IRRIGATION-INDUCED WATER QUALITY PROBLEMS (March 30, 1987)}

1987, 3 pp.

In its second letter report, the Subcommittee on Quality Assurance and Quality Control (QA/QC) of the CIIWQP to the San Joaquin Valley Drainage Program (SJVDP) recommends that the S.IVDP acquire a knowledgeable and experienced QA/QC manager. The subcommittec chairman was Robert R. Meglen, University of Colorado. The report is available from the Water Science and Technology Board, 2101 Constitution Avenue, N.W., Washington, D.C. 20418.

\section{LETTER REPORT OF THE COMMITTEE ON IRRIGATION-INDUCED WATER QUALITY PROBLEMS (February 17, 1987)}

1987, 1 p.

This is a one-page supplement to the first letter report of the Subcommittec on Public Health (dated, June 9, 1986) of the CIIWQP. It recommends that as the San Joaquin Valley Drainage Program evaluates the feasibility and desirability of potential actions to resolve agricultural drainage problems in the San Joaquin Valley, it should explicitly address the public health concerns that might be raised by such actions. The subcomnittec chairman was Edwin $H$. Clark of the Delaware Department of Natural Resources and Environmental Control. The report is available from the Water Science and Technology Board, 2101 Constitution Avenue, N.W., Washington, D.C. 20418. 


\section{NATIONAL WATER QUALITY MONITORING AND ASSESSMENT}

$198 \%, 108 \mathrm{pp}$.

This report, based on the second WSTB colloquium, discusses the need for a national water quality monitoring and assessment program for the United States. The colloquium chairman was Richard S. Engelbrecht of the University of Illinois. This report is available from the National Technical Infurmation Service, 5285 Port Royal Road, Springficld, VA 22161. NTIS Accession Number: PB 87-157467. List price: $\$ 18.95$.

\section{A REVIEW OF THE U.S. ARMY CONSTRUCTION ENGINEERING RESEARCH LABORATORY PROGRAM FOR RECYCLING AND REUSE OF A LAUNDRY AND SHOWER WASTEWATER}

1986, $104 \mathrm{pp}$.

This study evaluated the U.S. Army's Construction Enginecring Research Laboratory (CERL) program on recycling and reuse of field laundry and shower wastewater. It looks at technical and scientific merit, and recommends additional research needs necessary to achieve the goals of the program. The chairman was Richard $S$. Engelbrecht, University of Illinois at Urbana-Champaign, Illinois. The report is a vailable from the National Technical Information Scrvice, 5285 Port Royal Road, Springfield, VA 22161. NTIS Accession Number: PB 87-151726. List price: \$19.95.

\section{LETTER REPORT OF THE COMMITTEE ON IRRIGATION-INDUCED WATER QUALITY PROBLEMS (September 5, 1986)}

1986.? pp

The third letter report issued by the committec reviews research and related programs addre sing the agricultural drain- age problems in the San Joaquin Valley, California. The study committec was chaired by Jan van Schilfgaarde, USDA. ARS, Fort Collins, Colorado. The report is available from the Water Science and Technology Board, 2101 Constitution Avenue, N.W., Washington, D.C. 20418.

\section{LETTER REPORT OF THE COMMITTEE ON IRRIGATION-INDUCED WATER QUALITY PROBLEMS (July 8, 1986)}

1986, $6 \mathrm{pp}$.

This is the first letter report issued by the Subcommittec on Quality Assurance and Quality Control of the CIIWQP. The subsommittec chairman was Robert R. Meglen, University of Colorado. The report is available from the Water Science and Technology Board, 2101 Constitution Avenue, N.W., Washington, D.C. 20418.

\section{LETTER REPORT OF THE COMMITTEE ON IRRIGATION-INDUCED WATER QUALITY PROBLEMS (June 12, 1986)}

1986, 4 pp.

The first letter report issued by the Subcommittce on Public Health of the CIIWQP reviews the research proposed by the Ad Hoc Committee on Public Health of the San Joaquin Valley Drairage Progtam (SJVDP). The subcommittee chairman was Edwin $H$. Clark of the Conservation Foundation. The report is available from the Water Science and Technology Board, 2101 Constitution Avenue, N.W., Washington, D.C. 20418.

\section{GROUND WATER QUALITY PROTECTION: STATE AND LOCAL STRATEGIES}

1986, 309 pp.

This report reviews ground water protection strategies in ten states and threc 
local areas of the United States. The report provides a model for those looking to establish or improve ground water quality protection programs. The committee chairman was Jerome B. Gilbert, East Bay Municipal Utility District, Oakland, California. The report is available from the $\mathrm{Na}$ tional Academy Press, 2101 Constitution Avenue, N.W., Washington, D.C. 20418. List price: $\$ 24.50$.

\section{DROUGHT MANAGEMENT AND ITS IMPACT ON PUBLIC WATER SYSTEMS}

$1986,127 \mathrm{pp}$.

This report--the first in the WSTB's series of colloquia to focus attention on emerging issucs in water science, technology, and policy--addresses drought management and its impact on public water systems. The colloquium chairman was Robert L. Smith of the University of Kansas. The report is available from the National Academy Press, 2101 Constitution Avenue, N.W., Washington, D.C. 20418 . List price: $\$ 7.50$.

\section{LETTER REPORT OF THE COMMITTEE ON IRRIGATION-INDUCED WATER QUALITY PROBLEMS \\ (April 2, 1986)}

1986, $3 \mathrm{pp}$.

The sccond letter report from the Committec on Irrigation-Induced Watcr Quality Problems responds to bricfings provided by the University of California research program about irrigation drainage problems in the San Joaquin Vallcy. The committce chairman was William H. Allaway of Ithaca, New York. The report is available from the Water Science and Technology Board, 2101 Constitution Avenue, N.W., Washington, D.C. 20418.

\section{THE GREAT LAKES WATER QUALITY AGREEMENT: AN EVOLVING INSTRUMENT FOR ECOSYSTEM MANAGEMENT}

$1985,224 \mathrm{pp}$.

This report reviews the 1978 Great Lakes Water Quality Agreement between the United States and Canada. The report covers four major areas concerning the Great Lakes and the agreement: cnrichment, toxic contaminants, institutional arrangements and the ecosystem approach, and sustainable development. The committee co-chairmen were Orie Loucks of the Holcomb Research Institute, and Henry Regier of the University of Toronto. The report is available from the National Technical Information Service, 5285 Port Royal Road, Springfield, VA 22161. NTIS Accession Number: PB 87-186292. List pricc: $\$ 24.95$.

\section{LETTER REPORT OF THE COMMITTEE ON USGS WATER RESOURCES RESEARCH (November 26, 1985)}

1985, 9 pp.

This report recommends a focus for the rescarch grants program administered by the U.S. Geological Survey and authorized by section 105 of the Water Resources Rescarch Act of 1984. The committce chairman was James J. Morgan of the CaliCornia Institute of Technology. The report is available from the Water Science and Technology Board, 2101 Constitution Avenuc, N.W., Washington, D.C. 20418.

\section{LETTER REPORT OF THE COMMITTEE ON IRRIGATION-INDUCED WATER QUALITY PROBLEMS}

(October 10, 1985)

$1985,11 \mathrm{pp}$

This report, the first in a series pro- 
viding guidance to the San Joaquin Valley Drainage Program, calls for improved research coordination, better management, and public participation. The committec chairman was William $H$. Allaway of Ithaca, New York. The report is available from the Water Science and Technology Board, 2101 Constitution Avenue, N.W., Washington, D.C. 20418.

\section{LETTER REPORT OF THE WSTB WORKING GROUP TO REVIEW PLANS FOR A NATIONAL WATER QUALITY ASSESSMENT PROGRAM (October 7, 1985)}

1985, $3 \mathrm{pp}$.

This report was written by an ad hoc work group, consisting of Water Science and Technology Board members and $\mathrm{mem}$ bers of the Committec on USGS Water Resources Rescarch, in reaction to documents and briefings on the proposed National Water Qualit. Assessment Program. The workgroup chairman was Walter R. Lynn of Cornell University. The letter report is available from the Water Science and Technology Board, 2101 Constitution Avenue, N.W., Washington, D.C. 20418.

\section{WSTB REVIEW OF U.S. DEPARTMENT OF ENERGY (DOE) REPORT \\ "TRANSPORT OF ENERGY-RELATED ORG ANIC COMPOUNDS AND MIXTURES IN SUBSURFACE ENVIRONMENTS"}

1985, $6 \mathrm{pp}$.

In response to a request from the U.S. Department of Energy (DOE), an ad hoc subcommittce of the WSTB reviewed a DOE report titled "Transport of Encrgy Related Organic Compounds and Mixtures in Subsurface Environments" (November 1984). The DOE document was a "concept paper" describing a rescarch plan to be adopted by the department. The subcommittec chair was Mary P. Anderson of the University of Wisconsin-Madison. The letter report is available from the Water
Science and Technology Board, 2101 Constitution Avenue, N.W., Washington, D.C. 20481.

\section{SAFETY OF DAMS: FLOOD AND EARTHQUAKE CRITERIA}

$1985,321 \mathrm{pp}$

The report concerns the levels of salety to be provided at new and existing dams to withstand extreme floods and carthquakes. The report includes a thorough inventory of safety criteria for dams in use in the United States and internationally. The committec chairman was George W. Housner of the California Institute of Technology. The report is avail. able from the National Academy Press, 2101 Constitution Avenue, N.W., Washington, D.C. 20418 . List price: $\$ 16.50$.

\section{REVIEW OF THE GREAT LAKES WATER QUALITY AGREEMENT: WORKING PAPERS AND DISCUSSION}

1984, $174 \mathrm{pp}$.

The William H. Donner Foundation, in consultation with the staff of the International Joint Commission (IJC), asked the WSTB to study the Great Lakes Water Quality Agrecment. This report contains five formal papers, the discussion that followed each presentation, and a final summary chapter prepared by the Conference Advisory Pancl. The conference chairman was Orie Loucks of the Holcomb Research Institute. The report is available from the National Technical Information Scrvice, 5285 Port Royal Road, Springficld, VA 22161. NTIS Accession Number: PB 85-110807. List price: $\$ 17.50$.

\section{WATER FOR THE FUTURE OF THE NATION'S CAPITAL AREA - 1984}

1984, $71 \mathrm{pp}$.

This report reviews the Army Corps of Engineers methods investigating the fu- 
ture water resources needs of the metropolitan Washington area and to report the scientific bases for the conclusions reached. The committee chairmen were Daniel A. Okun of the University of North Carolina, and Walter R. Lynn of Cornell University. The report is avalable from the Water Science and Technology Board, 2101 Constitution Avenue, N.W., Washington, D.C. 20418 , and the National Technical Information Service, 5285 Port Royal Road, Spring. field, VA 22161. NTIS Accession number: PB 84-195585. List price: \$11.50.

\section{THE POTOMAC ESTUARY EXPERIMENTAL WATER TREATMENT PLANT}

$1984,135 \mathrm{pp}$.

This report was the culmination of an eight-year review of the U.S. Army Corps of Engineers study to determine the feasibility of using the Potomac cstuary waters as a source of water supply for the metropolitan Washington area. The committee chairman was Perry L. McCarty of Stanford University. The report is available from the Water Science and Technology Board, 2101 Constitution Avenue, N.W., Washington, D.C. 20418, and the National Technical Information Service, 5285 Port Royal Road, Springficld, VA 22161. NTIS Accession number: PB 84-195643. List price: $\$ 16.00$.

\section{THE LAKE ERIE-NIAG ARA RIVER ICE BOOM: OPERATIONS AND IMPACTS}

1984, 74 pp.

This report responds to a request from the International Joint Commission (IJC)--United States and Canada--to the NRC to assist in resolving issues associated with the ice boom located at the entrance to the Niagara River, New York and Ontario. The chairman was Harry L. Hamilton, Jr. of the State University of New York--Albany. The report is available from the National Technical Information Scrvice, 5285 Port Royal Road, Springfield, VA
22161. NTIS Accession number: PB 84-129709. List price: $\$ 11.50$.

\section{SAFETY OF EXISTING DAMS: EVALUATION AND IMPROVEMENT}

1983, 384 pp.

This text book-like report is to enhance dam safety and to provide guidance for achieving improvements in the safety of existing dams. The committec chairman was Robert B. Jansen, consulting enginecr. The report is available from the National Academy Press, 2101 Constitution Avenue, N.W., Washington, D.C. 20418. List pricc: $\$ 19.95$.

\section{LETTER REPORT: MAY 31, 1983 TO U.S. DEPARTMENT OF INTERIOR, U.S. GEOLOGICAL SURVEY AND OFFICE OF WATER POLICY}

This letter report responds to a USGS request for comments on an outline for the proposed National Water Summary 1983--Hydrologic Setting of Water-Rclated Issues. The chairman was Walter R. Lynn of Cornell University. The report is available from the Water Scicnce and Technology Board, 2101 Constitution Avenuc, N.W., Washington, D.C. 20418.

\section{COOPERATION IN URBAN WATER MANACEMENT, CONFERENCE PROCEEDINGS}

1983, 187 pp.

The WSTB held a conference in 1982 to assess the barricrs to efficient managcment of urban water supplies, titled "Cooperation in Urban Water Management" and produced this report. The conference chairman was David H. Marks of the Massachusetts Institute of Technology. The report is available from the National Technical Information Service, 5285 Royal Road, Springfield, VA 22161. NTIS Accession number: PB 83-217992. List price: $\$ 17.50$. 


\section{A LEVEE POLICY FOR THE NATIONAL FLOOD INSURANCE PROGRAM}

1982, $107 \mathrm{pp}$.

This report provides recommendations for integrating structural and nonstructural flood mitigation in the National Flood Insurance Program. The committee chairman was L. Douglas Iames of Utah State University. The report is available from the National Technical Information Service, 5285 Port Royal Road, Springfield, VA 22161.: Accession number: PB 83134619. List price: $\$ 13.00$.

\section{SAFETY OF NONFEDERAL DAMS: \\ A REVIEW OF THE \\ FEDERAL ROLE}

$1982,53 \mathrm{pp}$.

The recommendations in this report concern the enhancement of state dam safety programs. The committee chairman was Robert B. Jansen, a consulting engineer. The report is available from the National Technical In "ormation Service, 3282 Port Royal Road, Springfield, VA 22161. Accession number: PB 82-188855. List price: $\$ 9.00$. 


\section{Appendix B \\ Meetings of the Water Science and Technology Board and its Subgroups During 1989}

JANUARY

5-6 Committee on Coastal Erosion Zone Management Committec, Washington, D.C.

\section{FEBRUARY}

16-17 Committee on National Water Quality Assessment Pilot Program, Washington, D.C.

\section{MARCH}

2-4 Committee on Opportunitics in the Hydrologic Sciences, Beckman Center, Irvine, California

8-10 Committee on Irrigation-Induced Water Quality iroblems, Albuquerque, New Mexico

23-24 Committee on Coastal Erosion Zone Management, Beckman Center, Irvine, California

28-29 Committee on USGS Water Resources Research, Reston, Virginia

APRIL

6-7 Committee on Ground Water Recharge in Surface-Mined Areas, Pittsburgh, Pennsylvania

6-7 Subcommittee on Economics and Policy and Systems Analysis, San Francisco, California
19

19

20

$20-21$

$23-25$

\section{MAY}

8-9 Commmittee on Coastal Erosion Zone Management, Washington, D.C.

25-26 Committec on Western Watcr Management Change, Beckman Center, Irvinc, California

JUNE

19-21 Committee on Ground Watcr Recharge in Surface-Mined Arcas, Lexington, Kentucky

26 Committec on Glen Canyon Environmental Studies, Denver, Colorado 
JULY

6-7 Committee on Irrigation-Induced Water Quality Problems, Beckman Center, Irvine, California

20-22 Committee on Opportunities in the Hydrologic Sciences, Beckman Center, Irvine, California

\section{AUGUST}

21-22 Committee on Coastal Erosion Zone Management, Washington, D.C.

\section{SEPTEMBER}

7-9 Committee on Ground Water Recharge in Surface-Mined Areas, Billings, Montana

7-8 Committce on USGS Water Resources Research, Boulder, Colorado

14-15 Water Science and Technology Board, Woods Hole, Massachusetts

25-26 Committee on National Water Quality Assessment Pilot Program, Beckman Center, Irvine, California

\section{OCTOBER}

5-6 Committee on Restoration of Aquatic Systems: Science, Technology, and Public Policy, Wash. ington, D.C.

26-28 Committee on Western Watcr Management Change, Reno, Nevada

\section{NOVEMBER}

10-11 Committee on Opportunities in the Hydrologic Sciences Editorial Group, Cambridge, Massachusetts

16-18 Committee on National Watcr Quality Assessment Pilot Program, Beckman Center, Irvinc, California

20-21 Committee on Ground Water Rccharge in Surface-Mined Areas, Washington, D.C.

\section{DECEMBER}

4 Committee on Glen Canyon Environmental Studies, Washington, D.C. 


\section{Appendix $C$ \\ Terms of Reference \\ Water Science and Technology Board \\ (Adopted November 29, 1982)}

\section{INTRODUCTION AND PURPOSES}

The Water Science and Technology Board (WSTB) was established in the $\mathrm{Na}$ tional Research Council to provide a single focal point for studies related to water resources accomplished under the aegis of the National Academy of Sciences and the National Academy of Engineering. The Board's objective is to improve the scientific and technological basis for resolving important questions and issues associated with the efficient management and use of water resources.

In carrying out its responsibilities and to serve the national interest, the Board responds to requests for evaluations and advice concerning specific and generic issues in water resources; influences action by initiating studics of issues that merit consideration by public agencies and others; identifies issues and topics of rescarch related to water resources; and cooperates with other units of the National Research Council and groups with mutual interests outside the National Research Council.

The Board's scope covers the traditional scientific and engineering aspects of water resources and the economic, institutional, legal, educational, and social aspects, as well.

\section{AREAS OF INTEREST}

To pursue its objectives, the Board is concerned with:
- Basic hydrologic and related sciences and their applications in water resource systems, including analyses of ground water movement and the hydrologic cycle, measurement of water quantity and quality, data analysis, and forecasting.

- Planning, analysis, and operation of water systems, including resource management, water quality and quantity for all uses, public health and environmental protection, aquifer and watershed protection and management, economic analysis, design standards, modeling methods, risk assessment, system analysis techniques, and management systems.

- Nonstructural water resources issues, such as floodplain management, supply-demand relationships, water reallocation and reuse, effects of human activities on water resources, legal-institutional issues, ccosystem effects, and cultural and aesthetic values.

- Structural and traditional cngineering aspects of water projects, such as dams, levees, renovation-retrofit technologies, and treatment processes.

- The health and vitality of the nation's water-related science and enginecring establishment, including its educational aspects.

\section{GENERAL ACTIVITIES}

The Board strives to accomplish its purposes through the following means: 
1) Responding to specific requests by government agencies and others;

2) Reviewing and evaluating waterrelated research and scientific, engineering, and technological developments;

3) Initiating investigations of issues considered to be appropriate by the Board, its parent Commissions, and the Governing Board of the National Research Council;

4) Reviewing research and the stateof the art in science, engineering, and technology related to the development and management of water and related resources, especially in relation to national objectives and priorities;

5) Projecting future needs for and capabilities of multi-disciplinary waterrelated research and education in the sciences, engineering, and technology;

6) Disseminating the results of its studies, serving as a repository of scientific and engincering knowledge, and providing a forum for the exchange of information on water science and technolo.jy;

7) Fostering communication among members of the professional community in the United States on national and international water resources issues; and

8) Articulating water-related educational issues, including undergraduate, postgraduate, continuing education, and public-education programs and the related needs for equipment and facilities.

\section{ORGANIZATION AND MANAGEMENT}

\section{Governance and Relationship with Parent Bodies}

The Board, although responsible for its own immediate governance, is accountable to and supported by two Commissions of the Nationai Research Council--the Commission on Engineering and Technical Systems (CETS) and the Commission on Physical Sciences, Mathematics, and Resources (CPSMR)*. CETS is primarily concerned with the development and applica- tion of engineering disciplines to technological systems and their relationship to societal problems, while CPSMR is primarily concerned with basic sciences and their relation to resource identification and development and environmental management. For each of its specific technical, project, or administrative activities, the Board or its study groups will be responsible to and supported by either CETS or CPSMR.

The Board may undertake activities related to its mission such as conferences, seminars, and meetings. It may collaborate with professional associations and other groups as may be necessary to fulfill its goals.

The Board may recommend to the Chairman of the National Research Council and to the Commissions such changes in the purposes, responsibilities, size, and functions of the Board as it believes desirable.

\section{BOARD MEMBERSHIP}

To meet its broad need for expertise, the Board consists of not fewer than 15 and not more than 18 members in addition to its Chairman. Members are chosen for their background and experience as well as for their familiarity with appropriate scientific, technological, and policy issues. While serving on the Board, each member, insofar as possible, participates in at least one study conducted under the auspices of the Board.

Terms of appointment are normally for three years. Members are not eligible for more than two consecutive three-year terms. The Board Chairman is appointed by the Chairman of the National Research Council for a period not to exceed threc years. The Board nominates individuals for its own continuing membership.

When appropriate, the Board may invite federal agencies and organizations to nominate individuals to serve as nonvoting liaison representatives to the Board.

\footnotetext{
*Note: In February 1990 the CPSMR was disestablished. A new Commission on Geosciences, Environment, and Resources (CGER) was created. The WSTB was thenceforth responsible to the CGER and CETS. WSTB terms of reference will be modified accordingly.
} 


\section{STUDY GROUP ACTIVITIES}

The principal operating units of the Board are its separately appointed and individually inandated study groups. The Board, assisted by its staff, manages the activities of these units.

The Board exercises its oversight responsibility for ongoing studies by receiving reports from the chairpersons or staff and meeting with them as it deems appropriate.

The Board originates or reviews and approves nominations for membership on the study group committees and transmits its recommendations to the appropriate Commission.

The Board Chairman, with the approval of the Chairman of the appropriate Commission and the Chairman of the $\mathrm{Na}$ tional Rescarch Council, appoints chairmen and members of committees of the Board.

In recommending nominations for its committees, the Board seeks advice from both within and outside the National Research Council. Normally, members of committees or panels serve for the duration of a given study.

\section{REPORT REVIEW}

The Board reviews all reports that develop from its program in accordance with procedures and requirements established by the appropriate Commission and by the Report Review Committec of the National Research Council.

\section{BOARD MEETINGS}

The Board normally meets three times each year, twice at the NRC headquarters in Washington, D.C., and once elsewhere in the United States. Additional meetings are held as the Board decms necessary to carry out its responsibilities for planning, oversight, and review including, but not limited to, review and assessment of current activities; consideration and approval of new projects, proposals, and proposed memberships; technical and programmatic brief- ings; and discussions with government decisionmaking and policy personnel.

\section{PROGRAM PLANNING}

The Board, with the aid of WSTB staff, annually prepares a general plan of its proposed program of activities and projects for submission to the two Commissions, a icompanied by a request for authorization to receive outside funds for the support of these activities. The Board prepares reports on its activities as may be requested or required by the Commissions or the Governing Board of the National Research Council.

The Board Chairman and Staff Director present the Board's program plan and budget to the Commissions. New projects, approved by the Board, that do not appear in the approved plan and authorized budge: are brought to the appropriate Commission for action. The Chairman and Director also report periodically to the Commissions on any issues and problems of particular concern to the Board and any issues of broacier oope that may require a response of the Nativial Research Council.

The Boald formulates programs and requests funds in support of undertakings deemed to be logical, appropriate extensions of its approved program plan, subject to appropriate approvals.

The Board reviews all proposals for new activitics that require the use of outside funds. Proposals must be approved by the Board before a request for authorization to receive funds is submitted to the appropriate Commission.

Proposed projects are evaluated by the Board according to the following criteria: (a) the importance of the issuc to the nation relative to its water needs; (b) the availability of expert volunteers who can cnsure that the Board's contribution will bc appropriate, effective, and timcly; (c) the relevance of the work to the Board's areas of interest and competence, and (d) the involvement of policymakers of sufficient stature to ensure that the Board's response will have a significant impact. 


\section{STAFF}

The Board Director is responsible to the Chairman for the general management of the Board's program and to the executive Directors of CETS and CPSMR. The Director has the authority to hire additional staff members and or consultants necessary to assist in the overall management of the Board's progran, subject to the constraints and approvals of National Research Council policies and the administrative budget of the Board.

\section{EXPENSES}

Expenses of the Board and its study groups, including support of its staff and mectings, are ordinarily financed by grants or contract funds. 

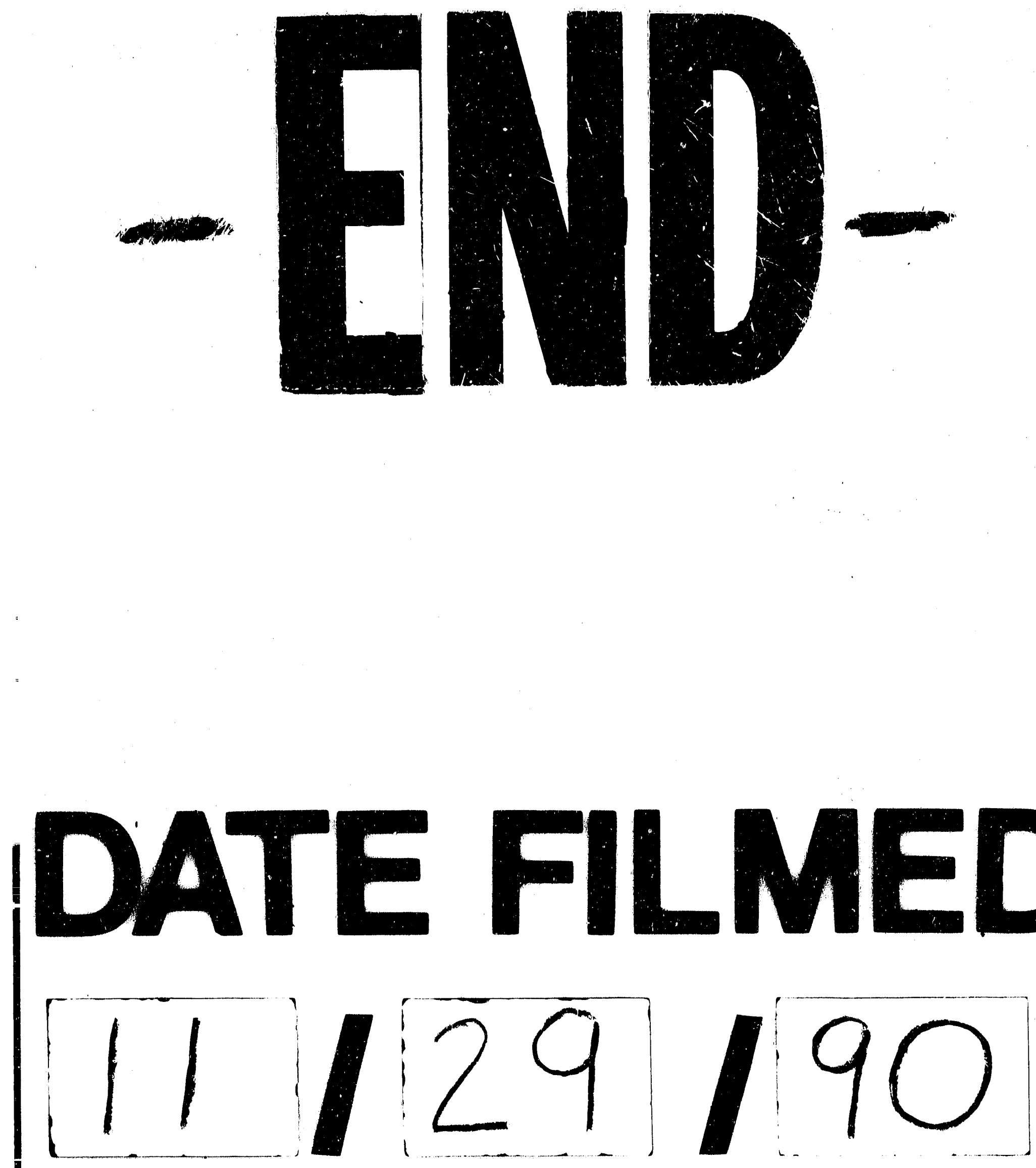


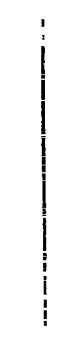

